NBER WORKING PAPER SERIES

THE PROPAGATION OF PRICES

IN THE OIL INDUSTRY

Avram Kisselgoff

Working Paper No. $2 \underline{45} \underline{\mathrm{R}}$

NATIONAL BUREAU OF ECONOMIC RESEARCH 1050 Massachusetts Avenue

Cambridge MA 02138

July 1980

Any opinions expressed are those of the author and not those of the National Bureau of Economic Research. 


\section{THE PROPAGATION OF PRICES IN THE OIL INDUSTRY $1958-1976$}

Avram Kisselgoff

\section{Abstract}

The main thrust of this report is the development of a price record that would provide a basis for the identification of the areas of activity in the oil industry in which significant price changes have occurred, with expectation that this type of information could serve as a useful ingredient in the policy-making process.

The study presents estimates of the selling price of a barrel of oil at three stages of operations of the industry -- the wellhead. the refinery and the end-use levels. Prices of individual classes of petroleum products at refineries and at the end-use level were also estimated. The price data are provided for benchmark years 1958, 1963, 1967 and 1972, as well as for 1973, 1974, 1975 and 1976 when crude oil prices rose considerably. The estimating procedure is briefly described in the study.

The examination of the transmission of prices from market to market within the oil industry shows that the steep rise in 1973-74 prices paid by end-users of petroleum products was due not only to the large increases in crude oil prices but also to the sizable increases in gross operating margins-labor costs, transportation, profits, etc. -- at the refinery and distribution levels. In the post-embargo years of 1975 and 1976, prices continued to advance but at a slower pace. The refiners' gross margins in 1975, however, declined somewhat; they rose significantly above the 1974 level in 1976. The marketers' margins made further gains in 1975, but exhibited a decrease in 1976. Another finding is that during 1973-74 there was a considerable narrowing in the price differentials among the various refined products; in particular the price of residual fuel oil, which averaged 20 percent of the price of gasoline in the decade of the 1960's, rose to 52 percent of the price of gasoline by 1974. The narrowing process continued in 1975-1976.

The study includes a short discussion of the effects of rising oil prices in 1973-1976 on the profitability of the petroleum industry and the general price level.

Avram Kisselgoff

National Bureau of Economic Research 15-19 West 4 th Street

New York, N.Y. 10012

Tel: (212) 598-3532 
The Propagation of Prices in the Oil Industry, 1958-1976*

AVRAM KISSELGOFF

The ongoing inflation in the United States, which began in the midale 1960's, has produced an extensive literature on both its causes and remedies. Despite a great number of studies, some of them quite enlightening, dealing with the factual, theoretical and policy aspects of inflation, the problem appears to be now as intractable as ever.

The inflationary process can be viewed generally as a propagation of rising prices through the economy, with the rates of increase modified by the structures of the sectors and special forces affecting them and resulting in an upward movement in the general price level.

Numerous hypotheses as to the origin of inflation and the relative importance of sporadic domestic and external events as well as persistent long-run influences expected to play a role in its generation have been formulated and tested, contributing considerably to the understanding of the problem of inflation. Recently, particular effort has been made to investigate the transmission of inflation through the economy. Most of the emphasis in this area, however, has been on the macroeconomic level, leaving the movements of prices from market to market within individual industries largely unexplored. This study represents a modest effort to

* I wish to acknowledge helpful comments from Robert Iipsey, Joel Popkin, Jack Goldstein, and some members of the petroleum industry whom I found highly informative. I am also grateful to Robert lewis for providing me with some valuable data. For financial support I am indebted to the National science Foundation. The evidence and conclusions set forth here are solely my own. This study draws on many sources; in particular, I should mention two works: Price Making and Price Behavior in the Petroleum Industry, by Ralph Cassady, Jr. and Competition in Oil, by Daniel C. Hamilton. 
increase our knowledge of this process, as an aid in the development of anti-inflationary policy measures.

One can associate the current inflation in the United states with the intensification of the war in Vietnam under President Johnson which was largely financed through budgetary deficits and not conventionally, through taxation. As a result, new pressures were added to already high levels of utilization of the country's resources. coinciding in time, the rapidly expanding new social programs and various stimulative measures in selected areas of economic activity had a tendency to create in a short span of time considerable increases in demand for services and goods without a corresponding rise in supply and thus generate upward pressures on the price level. Since 1964 the monetary policy of the country has been generally expansionary and with the exception for a short-lived tightening on some occasions, it has produced conditions that have validated the rising demands, particularly through a generous extension of credit. There is also some evidence that shortages of raw materials in recent years, partly due to very long lead times on the supply side, have contributed significantly to the sharp rise in wholesale and consumer prices. The development of serious domestic market imbalances was accompanied by a series of strong external shocks aggravating the current inflation. Among the disturbances that should be noted for their serious impact on the economy are: the devaluation of the dollar and the resulting rise in import prices; the abnomally large purchases of agricultural commodities in the U.S. by the soviet Union causing shortages and driving up food prices; and a drastic increase of oil prices by the organization of Petroleum Exporting Countries (OPEC). 
The purpose of this report, which is a part of a larger study, is to investigate the price behavior of the petroleum industry in the 1958-1976 period, with the hope that it may help to shed some light on the role of the 1973-74 sharp increases in oil prices in the current inflation. To be more precise, the main thrust of this report is the development of a price record that would provide a basis for the identification of the areas of activity in the industry in which significant price advances have occurred, with expectation that this type of information could serve as a useful ingredient in the policy-making process.

\section{The Markets of the Petroleum Industry in the U.S.}

Domestic operations of the petroleum industry are generally divided into three major successive stages: the production of crude oil, the refining of crude into finished products, and the marketing of such products. Although the industry performs other functions, such as exploration and drilling on the production level and transportation of crude to refineries, these functions, however important and indispensible they are, may be considered as services incidental to production and processing of oil. This study will be concentrated on the movement of prices through the three successive stages of the petroleum industry.

Despite the long-running heated controversy as to whether the petroleum industry is characterized by a low or high degree of competition. it is difficult to contest the fact that there are separate and substantial markets: (I) at the wellhead level, for crude oil;

I) A study of Inflation, 1964-1974, by A. Kisselgoff and J. Popkin, a project financed by The National science Foundation. Dr. Popkin has completed his part of the project and is in the process of preparing the study for publication. 
(2) at the refinery level, for finished products, and (3) at the end-use level, for finished products incorporating marketing services.If The nature of these markets, in which large and small concerns participate, stems from the structure of the petroleum industry. Although there is much integration in the industry, even the most integrated companies are not self-sufficient. $2 /$ Generally, these companies produce more or less crude oil than they refine and refine more or less products than they market. There are also partially integrated concerns. Some of them produce crude and operate refineries, but do not possess marketing facilities. Some of them refine and market, but buy crude from other firms. Moreover, there are non-integrated producers of crude, non-integrated refiners and non-integrated marketers. As a result, all the companies in the industry in various degrees must have recourse to the markets in which they appear as buyers or sellers or both in order to be able to carry out their operations. Obviously, if all the companies in the petroleum industry would be fully integrated and balanced, there would be only one market in which finished products are sold to the ultimate consumers. Since this is not the case, even the most integrated companies cannot fully by-pass the intermediate markets.

Table 1 shows the extent to which the refineries of the top eight companies are integrated between production and refining, with the degree of self-sufficiency measured by the ratio of each company's refinery input to its own production of crude. The table also gives the companies' shares in total domestic production of crude.

1) Another way of viewing the petroleum industry would be as an industry composed of the three major areas of activity with markets for crude and products connected by refining as an independent industry.

2) See Daniel C. Hamilton, Competition in Oil, Chapter 2. 


\section{Table 1}

Estimates of the Domestic Self-sufficiency of the Eight Largest Oil Companies and Their Shares in U.S. Crude Production, 1969

\begin{tabular}{lcc}
\hline Company & $\begin{array}{c}\text { Shares of U.S. } \\
\text { Crude Production }\end{array}$ & $\begin{array}{c}\text { Self-sufficiency } \\
\text { Ratio }\end{array}$ \\
$\begin{array}{l}\text { Exxon } \\
\text { Texaco }\end{array}$ & $9.8 \%$ & $(1)$ \\
Gulf oil & 8.5 & $87.4 \%$ \\
Socal & 6.8 & $81.0^{\mathrm{b}}$ \\
Standard of Indiana & 5.3 & $87.6^{\mathrm{a} . \mathrm{d}}$ \\
ARco & 5.0 & $68.8^{\mathrm{a}}$ \\
Shell oil & 5.1 & $50.5^{\mathrm{a}}$ \\
Mobil oil & 6.0 & 64.9
\end{tabular}

I/ Getty's self-sufficiency ratio in 1969 was $137.2 \%$ and its share in total production of crude. $3.4 \%$. Getty, as a producer of crude, is the ninth company in the order of importance.

a-Other liquids includes in crude production. b-Estimated. c-other liquids included in refinery runs. d-Excludes crude processed for company's account.

Source: Federal Trade Commission, Preliminary Trade Commission Staff Report on its investigation of the Petroleum Industry, 1973. Pp. 13, 20 . 
John M. Blair in his book, The control of Oil, provides an estimate of self-sufficiency of $71.7 \%$ for all eight top companies combined.1/ These companies also accounted for $50.4 \%$ of total domestic production of crude.

According to Mr. Ted Eck of Standard Oil of Indiana, quoted by The Twentieth Century Fund report, non-integrated companies accounted in 1974 for about 30\% of refining and $29 \%$ of marketing. $2 /$ These are relatively substantial markets where the output of nonintegrated companies and part of the output of integrated companies are traded and prices are established. Since this study is concerned with the movements of prices for the total output of the oil industry, the same prices that prevail in these markets also will be considered as representative of that integrated output moving outside the market channels.

\section{Some Background Remarks about the Industry}

Crude oil is not a single product, but a range of products. There are actually hundreds of different types of crude, reflecting primarily variations in gravity and sulphur content. correspondingly, there are hundreds of wellhead prices.

Historically, crude prices, though generally on the rise since early 1940's, have shown a tendency toward stability in the short run. A major factor underlying this tendency has been the restrictions

1 Companies that are integrated in at least three functions production, refining and marketing - are generally known as majors. Dr. John Blair in his book, The Control for oil (1975), calls as "lesser majors" those companies which are important only in one stage, although they stili can be engaged in operations in other stages. Non-integrated companies are classified as independents.

2/ Report of the Twentieth Century Task Force on United States Energy
Policy, Providing for Energy, p.98. 
imposed by various oil-producing states upon production of crude in accordance with market demand as estimated by the Bureau of Mines and the principle of avoiding physical waste (a concern that can be traced back to the turn of the century). In 1959 this control of domestic supply was supplemented by crude oil import quotas. The quotas were eliminated in 1974. These restrictive measures generally operated efficiently over time as they kept the imbalance between supply and demand for crude to a minimum. It should be noted, however, that some fluctuations in crude prices have taken place even when there has been adequate total supply due to active competition among individual companies in short supply. Generally, companies desiring to purchase domestic crude oil post their prices (on this level of operations prices are set by the buyers), but significant quantities of crude are still sold at prices varying from posted quotations due to special situations.

According to the American Petroleum Institute, U.S. refineries turn out from crude oil more than 3,000 products or gradations of products. Customarily, these products and gradations of products are grouped into classes of products. For 1972, the year before the explosive upsurge in oil prices, the Bureau of the Census gives the following distribution by major product classes of the value of refinery output shipped and transferred between plants by all manufacturing establishments: I/

1/ The value of interplant transfers constitutes a very small proportion of the total value and therefore no significant error is introduced in the computations by ignoring it.

Source: Annual Survey of Manufacturers, 1974. General statistics for industry groups and industries, U.S. Department of Commerce, Bureau of the Census. 
Product Classes

1. Gasoline

2. Distillate Fuel oil

3. Jet Fuel

4. Iiquefied Refinery Gases

(feedstock and other uses)

5. Residual Fuel Oil

6. Lubricating oil \& greases made in refineries

7. Asphalt

8. Kerosene

9. Other finished petroleum products

Total

\begin{tabular}{|c|c|}
\hline $\begin{array}{c}\text { (millions of } \\
\text { dollars) }\end{array}$ & $\begin{array}{l}\% \text { of } \\
\text { Total } \\
\end{array}$ \\
\hline 13.029 .6 & $52.6 \%$ \\
\hline 4.407 .7 & 17.8 \\
\hline $1,371.6$ & 5.5 \\
\hline $1,152.9$ & 4.7 \\
\hline $1,107.2$ & 4.5 \\
\hline 894.8 & 3.6 \\
\hline 671.5 & 2.7 \\
\hline 372.4 & 1.5 \\
\hline $1,765.1$ & 7.1 \\
\hline $24,772.8$ & $100.0 \%$ \\
\hline
\end{tabular}

It can be seen from the above data that the three most important classes of products are gasoline, distillate fuel and jet fuel. Together they accounted for about $76 \%$ of the total value of domestic output. The percentage yields of refined products from crude oil in the United states published by another Federal agency, the Bureau of Mines, indicate that the same three classes of products also represented $76 \%$ of the total physical output of refined products in 1972, but with gasoline accounting for $46.2 \%$, distillate oil for $22.2 \%$ and jet fuel for $7.2 \%$. Because of the great importance of gasoline anong petroleum products, the principal activities of the oil industry at the refinery and marketing levels are to a large extent related to this product. since refining is a joint-product production of complementary type and calls for continuous operations of the plants at the maximum level in order to keep costs to a minimum, the supply is not easily adjusted in the short run to unexpected changes in demand for individual products. 
Moreover, because of the tax advantages that the petroleum companies engaged in crude production enjoyed in the past. there were obvious reasons for them to keep crude output at the highest level compatible with demand, thus putting upward pressure on the refineries' capacity utilization. $1 /$ with these factors present, conditions were created generating intensive competition among the companies as they tried to dispose of the refineries' products in order to maintain uninterrupted the flow of crude oil.

At the refinery level there is a considerable amount of intercompany product exchanges and product sales arising from supply and demand imbalances. The non-integrated refiners generally sell their products wholesale to resellers or directly to large buyers industrial and commercial concerns, utilities, and governmental agencies - for their own use. The integrated companies, to the extent that they refine products in excess of what they can hande through their own distribution systems; dispose of the surplus by selling it to other distributors.

Wholesale prices at which refiners sell their products are customarily posted but also are often negotiated between sellers and buyers. Prices charged to other refiners as well as to resellers and large ultimate consumers usually vary with the transaction volume and when they are a result of contractual arrangements also depend on many other considerations.

The marketing system for refined products is large and complex.

1/ Depletion allowances were eliminated for the major oil companies on December 31, 1974, while deductions of intangible drilling expenses have been maintained. 
Some products flow directly from the refineries to consumers, others flow through a number of intermediaries. A general, greatly oversimplified structure of the distribution channels of the market for finished oil products, particularly in the nonintegrated segment of it, can be described as follows: $1 /$

1. Independent refiners generally make direct sales to other refineries (sometimes using brokers), to large non-refinery suppliers, to jobbers, to wholesale cooperatives, to large ultimate consumers (industrial and commercial accounts and governmental agencies) to retail dealers or only to some of them. $2 /$

2. The large non-refinery suppliers resell the products to jobbers and also directly to retail dealers.

3. The jobbers and wholesale cooperatives resell the products to retail dealers and retail cooperatives.

4. Retail dealers and retail cooperatives sell the products to the ultimate consumers (which include small agricultural and commercial accounts and cooperative members).

The first three levels of distribution involve sales at wholesale prices. As the products move forward from one level to another. closer to the ultimate consumers, prices generally increase, since

1/ The various deviations from the presented scheme are too many to be
listed here.

2/ From the refineries gasoline often moves to terminals or bulk stations, from which it is reshipped in reduced volumes to service stations or large ultimate consumers. Iarge suppliers and jobbers may also own (or rent) bulk stations through which they distribute refined products. 
various costs, including those of transportation and profits, are added on each level. At the retail level, prices for the same reason obviously increase further.

The integrated companies, which produce the bulk of refined products in this country, have their own marketing organizations. These organizations are generally built around terminal and bulk stations, from which refined products move through various links down to the retail establishments which are owned either by the companies or by the dealers or resellers, or are sold to large commercial consumers. When the integrated concerns produce refined products in excess of their own marketing needs, they appear as sellers in the refined products market.

Although in the past the custom in the petroleum industry was to post prices, in practice the posted prices generally represented only a point of departure for negotiations and often differed significantly from the actual prices.1/ Recently, deviations from the posted prices have been much less frequent.

It is obvious from the even cursory discussion of the structure of the petroleum industry and its main operations, involving thousands of products and gradations of products, that the study of the price behavior in the industry, in order to be manageable, would have to be carried out on a high level of aggregation. An efficient way of accomplishing this is to use a 42 gallon barrel as a yardstick for

1/ The tank wagon price (the price at which sales are made to retailers and some commercial consumers) is a key price in petroleum product distribution. It provides a basis for the determination of the jobber's margin and the retailer's margin. This price, however, in its turn moves upward or downward with changing market conditions. 
the measurement of overall oil prices on each of the three successive stages of the industry's operations. Prices of (1) a barrel of crude oil at the wellhead, (2) a barrel of products at the refineries, and (3) a barrel of refined products at the end-use level, together should form a convenient framework for the examination of the propagation of prices at any given point of time and over time. To be valid, however, this approach requires that the composition of the barrel's products does not show significant changes between stages and over time. The evidence provided by the Bureau of Mines in the form of annual percentage yields of refined petroleum products from crude oil in the united states, Table 2, indicates considerable stability in the composition of refined products produced. I/ However, to the extent" that changes did occur in the composition of the barrels on the three stages of operation over time, some inaccuracy is introduced in calculations.

1/ The stability is even more marked if "kerosene" and "jet fuel" percentages are combined. It should be noted, however, that since 1972 the percentage of residual oil produced has been on the increase, reflecting the expanding domestic demand for this product in certain regions of the U.S. 


\section{Table 2}

Percentage Yields of Refined Petroleum Products from Crude 0 il in the United States, 1958-1976

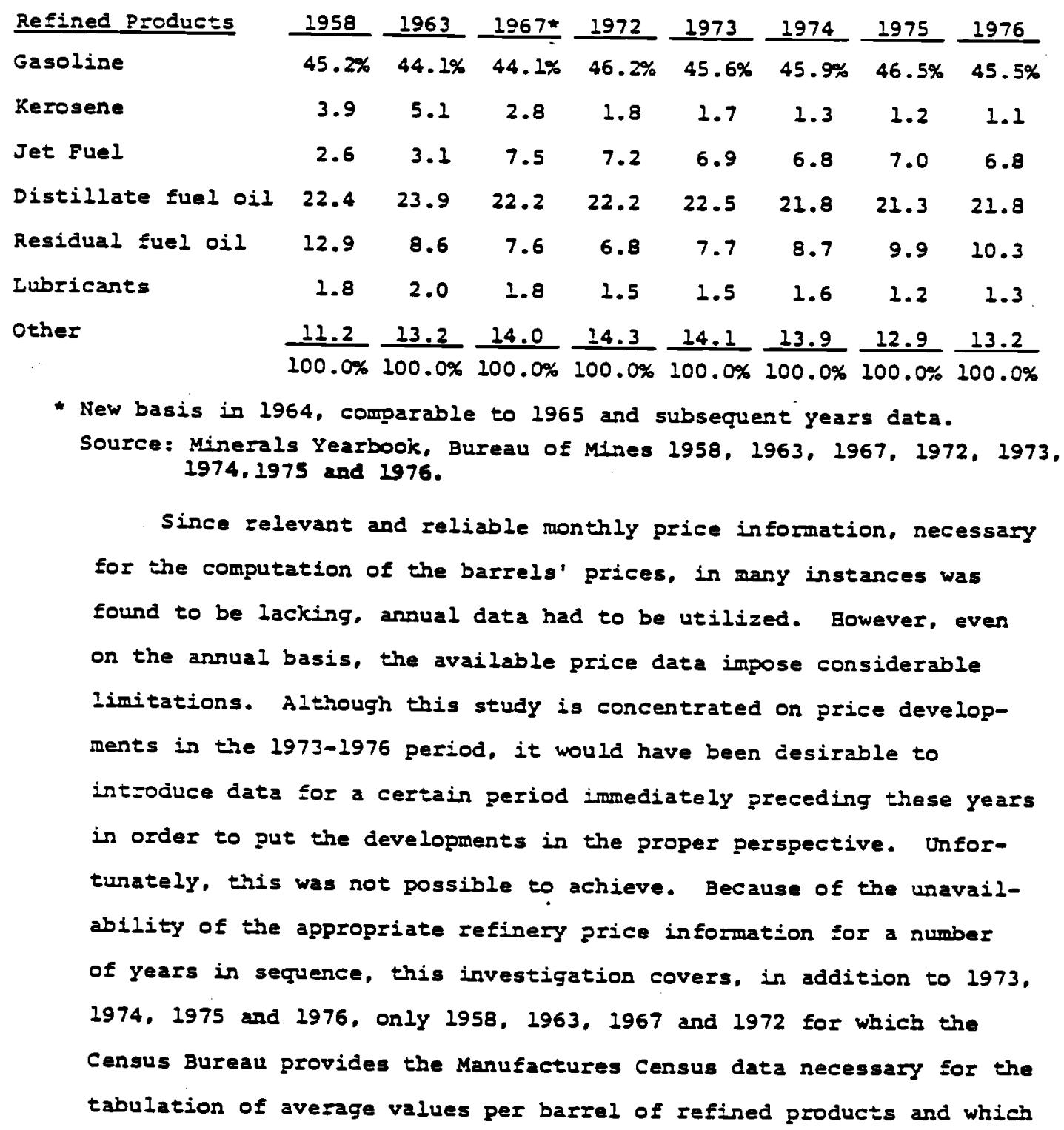


can be considered as a good approximation of their prices. I/ The terms "price" and "average value" will be used interchangeably in the text.

Estimation of Prices of Oil on a Barrel Basis at the Three Stages of Operations in the Petroleum Industry

1. Crude Oil Prices

In the computation of crude prices two series reported by the Bureau of Mines were employed:

(a) annual totals of U.S. value of crude oil (including lease condensate) at the wellhead, and

(b) the number of barrels produced during the corresponding years.

The annual value averages per barrel obtained on the basis of these two series may be considered as representative of the price levels of crude and, like the posted prices, they do not include transportation charges. Since 1973 and 1974 prices of imported crude were much higher than those of domestic crude, composite prices of both (weighted by the corresponding quantities) were used in calculations. $2 /$ Before 1973 the refiner's acquisition costs (prices of crude plus transportation charges) of a barrel of imported crude and that of domestic crude were reported by the refineries to the Bureau of the census to be about the same.

\section{Refinery Product Prices}

Because of the multiplicity of products processed by the

1/ The calculated average values (or census unit values) are equivalent to weighted averages of all transactions prices for the products involved where the weights are the amounts of individual transactions.

2/ For 1973 and 1974 prices of imported crude were provided by the Federal Energy Administation. 


\section{$-15-$}

refineries out of crude oil, classes of products were used as a basis for the estimation of a barrel price of refined products. Basic information necessary for computation is provided by two sets of data:

a) annual percentage yields of refined petroleum products from crude oil in the United states as reported by the Bureau of Mines; and,

b) annual values and quantities of shipments and interplant transfers of refined products distributed per class of products as reported by the Census of Manufactures for the years 1958, 1963, 1967 and 1972. For 1973, 1974, 1975 and 1976, for which annual values of shipments and interplant transfers per class of products with the corresponding quantities are not available, wholesale prices of the most representative product of the class of products at refineries in oklahoma, as reported by the Platt's service, were used after adjustment for the level of the average value of the corresponding class of products in 1972 (census data). These data allow the computation of annual average selling prices of the refined products yielded by a 42 gallon barrel of crude.

By multiplying the percentage yields for any given year by 42 gallons, a distribution of output of a barrel of refined products among its classes of products are obtained. The gallonage figures then are multiplied by the corresponding average values of shipments and interplant transfers per class of products. The sun of the tabulated values of the classes 
of products represents the estimated price of a barrel of products at the refinery level. I/ An example of such computations is given in Table 3 .

I/ A test based on detailed data reported by the censuses of Manufactures for 1958 and 1963 showed that the effect of changes in the composition of the two principal classes of products - distillate fuel oil and residual fuel oil - on the average values of these classes of products was rather small (from $1 \%$ to $4 \%$ ). 


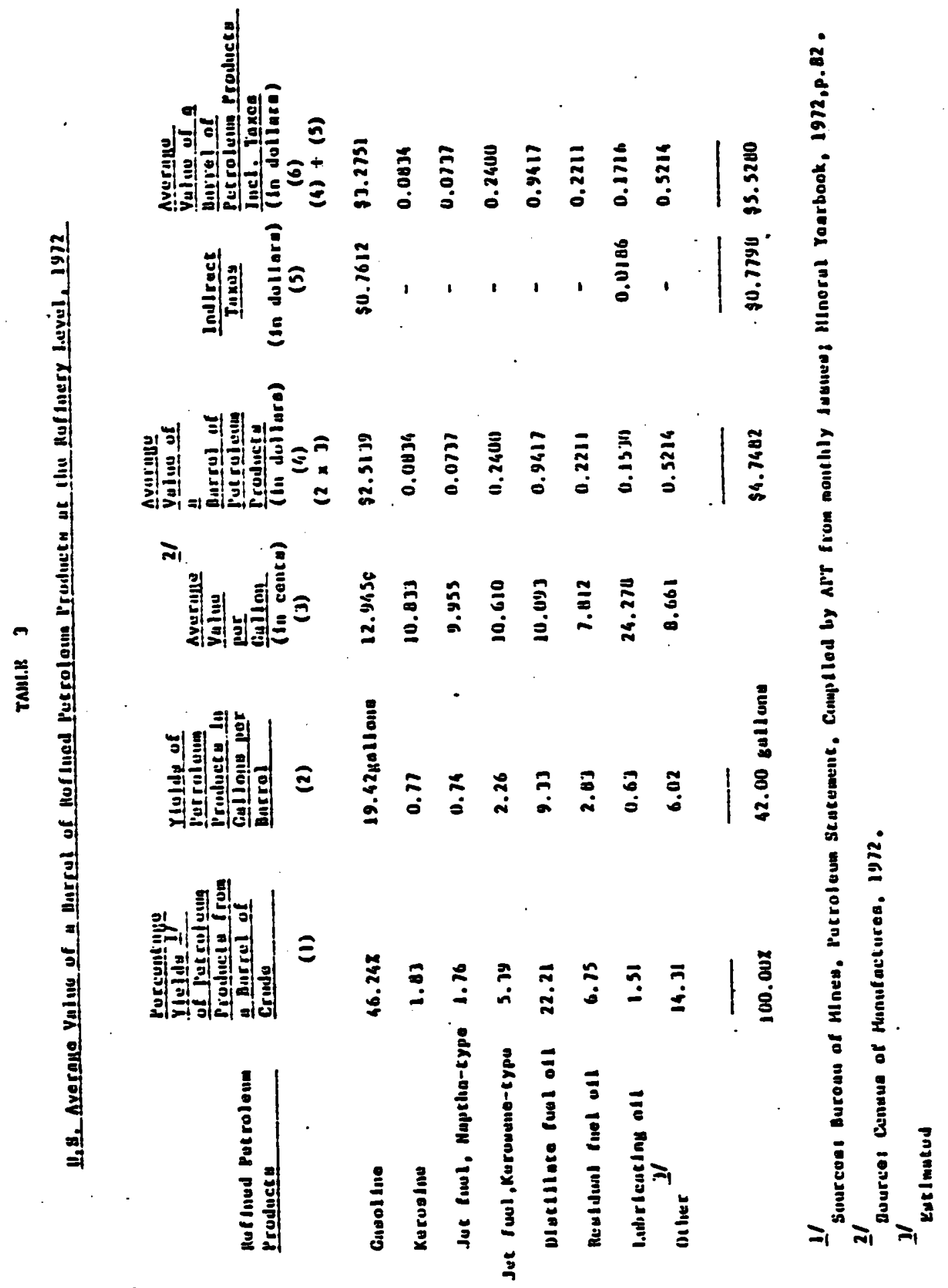




\section{End-Use Prices of Refining Prices}

Petroleum products produced by refiners are sold either for resale or to ultimate consumers. At the end-use level, utlimate consumers purchase not only the part of the output that is sold directly to them by the refineries, but, obviously, also the remaining part of this output that reaches them through the intermediaries. The latter part of output is acquired at higher prices, because these incorporate, in addition, to prices charged at the refinery level, also the cost of marketing. Thus, the basis for the estimation of the price of a barrel of refined products at the end-use level should be the same barrel of products as on the refinery level, without any change in its composition. On the end-use level, however, the same class of product of the barrel is generally put to various uses by the final consumers. A shortened list of these uses and the relative importance of purchases by users in the total of each product class marketed in 1972 is as follows: 
Table 4 I'

O.S. Percentage Distribution of Refined Petroleum Products der Use, 1972

Gasoline

Elghway use

Non-highway use

Total gasoline

\section{Rerosene}

Range ofl use

Other uses

Total kerosene

Jet fuel

Naptia-type

Rezo-type

Total jet Euel

Distillate fuel oil

Eeating oil (No. 1, No. 2, No. 4)

Indust 5

Electric Dtilities

Railroads

Vessel bunkering

Diese1-type

(a) on highway

(b) off highway

All other2/

Total distillate fuel oil

$17 \%$

$5 \%$

Residual fuel oil

Heating o:l (No. 5, No. 6)

Industrial

Electric utilities

Vessel bunkering

011 company fuel

All other $2 /$

Total Residual fuel oil

Iubricants

Automotive use

Industrial and other

Iotal lubricants

Other products $2 /$
Z of Domestic Sales

$98 \%$

$\frac{27}{1007}$

$77 \%$

$23 \%$

$1 \overline{100 z}$

23\%

$\frac{77 \%}{100 \%}$

517

$6 \%$

$6 \%$

$9 \%$

2\%

$22 \%$

$\frac{47}{100 \%}$

$21 \%$

$15 \%$

$47 \%$

$8 \%$

$5 \%$

$4 \%$

$\frac{4 \%}{100 \%}$

$49 \%$

$\frac{51 \%}{100 \%}$

$100 \%$

I/ Percentages are computed on the basis of data contained is the Annual Statistical Review, Petroleum Industry Statistics, 1965-197, American Petroleum Insisute, May 1975.

2/ Uses are estimated rougily. Includes adjustments to allow total of uses shown to equal total domestic demand. 
on the basis of the percentage distribution of the 42 gallon barrel of refined products per class of products and the percentage distribution of products within each class of product per use, it is possible to obtain a corresponding distribution in gallons.

When the appropriate prices charged to ultimate consumers are multiplied by the estimated gallonage data within each class of products and the values so computed are added up and then divided by the total gallonage for each class of products, an average price for each class of products at the end-use level is obtained. These average prices when multiplied by the corresponding gallonage of classes of products will yield values whose sum may be considered as a reasonable approximation of a price of a barrel of refined products purchased at the end-use level. $1 /$

Prices used in these computations, however, are not readily available. Because prices for the same class of refined products charged to various categories of users are generally different as they vary with the size of delivery, method of delivery, length of contract, market conditions, etc., the search for the relevant price data necessitated the use of all of its three major sources: government, industry and consumers. As a by-product of this effort, it was possible to develop time series of prices on an annual basis for the most important refined products purchased by the final consumers.

The Level of Prices on the Three stages of operations

The table below presents the results of these computations. While revealing, they are not surprising.

1 Since sales for export (and they represent rather a small proportion of total sales) are not taken into account explicitly, some error is introduced in the estimates (this will occur when prices for exported products differ from prices of the same products sold for other uses). 


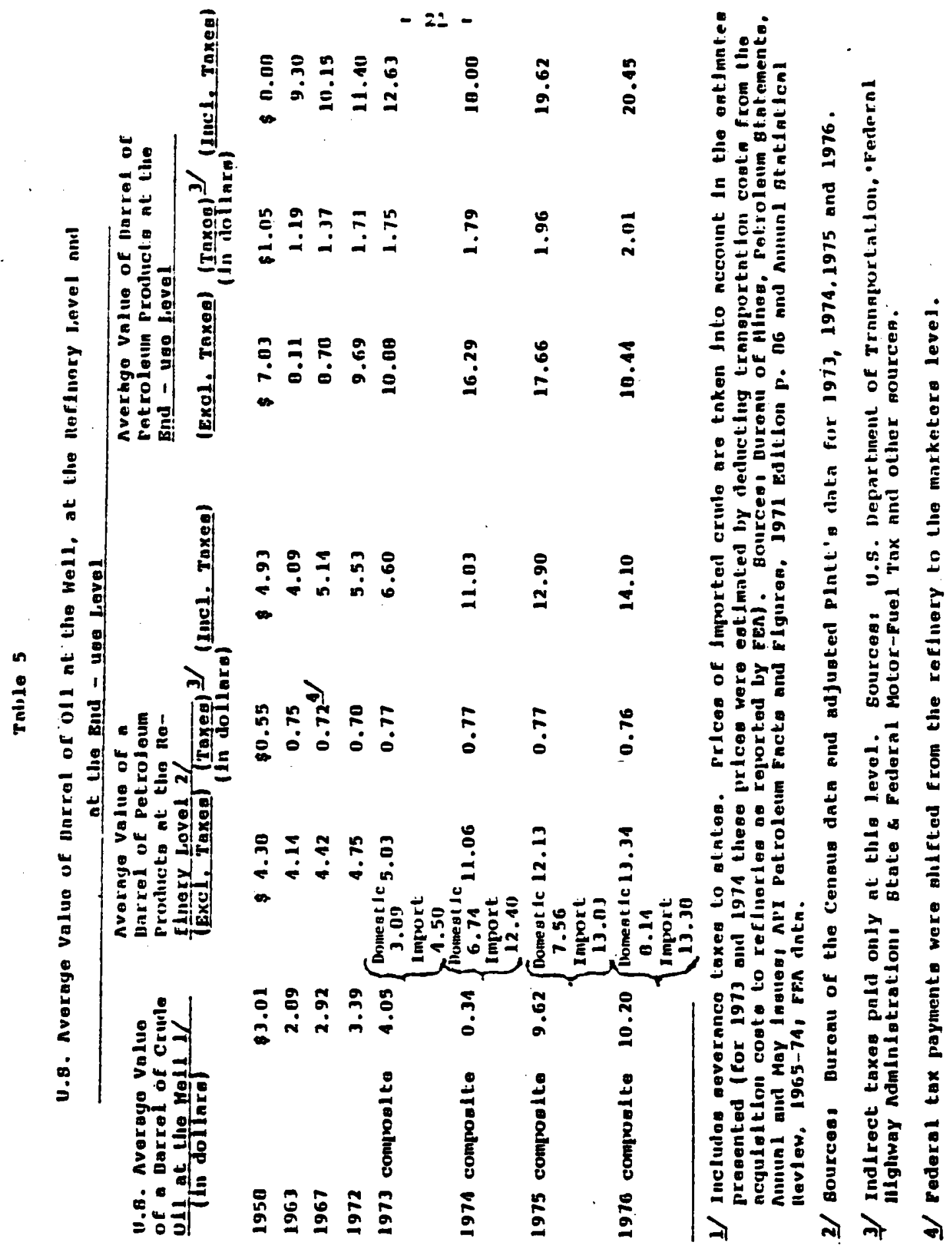


The price of domestic crude which stood at $\$ 3.02$ a barrel at the wellhead in 1958, declined to $\$ 2.89$ in the following year, and then showed little change until 1967. From $\$ 2.92$ in 1967 the price was on the uptrend to 1971, when it reached the level of $\$ 3.39$; it held at that level in 1972 .

In 1973 the average price per barrel moved up to $\$ 3.89$, a gain of $14.7 \%$ over a year earlier. During 1973 two important developments took place: (1) the system of import quotas, in existence for 14 years, was abandoned on April 17 as the domestic production of crude continued the decline from its peak in 1970 and the domestic demand for petroleum products continued to expand rapidly, creating an increasingly greater need for the importation of foreign oil, and the establishment by the cost of Iiving council (CIC) on August 17 of a two-tier pricing system exempting from ceiling prices "new oil" (oil produced above the 1972 level) in order to stimulate production. These developments in conjunction with the completely unexpected sharp advances in prices of foreign crude and petroleum products in 1973 had a profound impact on the U.S. oil markets.

On October.6, 1973 Arab countries declared an embargo on oil shipments to the United states which was followed by large price increases in exported oil. On october 16 the organization of Petroleum Exporting countries (OPEC) raised the posted price of a barrel of crude oil, as measured by Saudi Arabia light, from $\$ 3.01$ to $\$ 5.11$ in June and further to $\$ 11.65$ in December 1973. It may be observed that as recently as 1970 the price of the Saudi Arabia light was still at the long-established level of $\$ 1.80 .1 /$

I/ Source: World Wide Crude Oil Prices, Office of Oil and Gas, U.S. Dept. of Interior, Middle East Economic Survey, and Petroleum Economist (Blair, p. 262). 
The U.S. average price of imported crude for 1973 was estimated at $\$ 4.50$ per barrel. In 1974 it increased sharply to $\$ 12.40$ or $175.6 \%$ greater than a year before.

With respect to prices of domestic crude, the effect of the elimination of the price ceiling prices for "new oil" in August, 1973 was almost immediate and such prices moved rapidly to the world market levels. Between september and December 1973, the price of "new oil" increased from $\$ 5.12$ to $\$ 9.51$ per barrel. Between January and December 1974, the price per barrel advanced from $\$ 9.82$ to $\$ 11.08$. The prices for old or controlled oil also were adjusted upward. They were allowed, after CLC granted two significant increases in the first half of 1973 , to rise from $\$ 3.90$ per barrel in August to $\$ 5.25$ in December. In 1974 the price remained at the $\$ 5.25$ level throughout the year.

The average composite price of all domestic crude, "new" and "old", at the well jumped from $\$ 3.89$ in 1973 by $73.3 \%$ to $\$ 6.74$ in 1974. In the post-emioargo years of 1975 and 1976, the composite price per barrel continued its advance. In 1975 it rose by $12.2 \%$ to $\$ 7.56$ and in 1976 by $7.7 \%$ to $\$ 8.14$.

Since the U.S. refineries in their production of refined products have used, in addition to domestic crude, also a certain proportion of imported crude, total costs of crude purchased, obviously must reflect the prices of its two components. The data provided by the Bureau of Census indicate that the refiners' acquisition costs (price of crude plus transportation cost) for both domestic and foreign oil was about the same in 1958, 1963, 1967 and 1972.

This occurred in a period when prices for foreign crude oil were significantly cheaper than those of domestic crude oil as evidenced by the existence of prices on import "tickets" (allocations) that 
emerged under the quota system and which became stabilized at around $\$ 1.25$ per barrel. $1 /$

In the computations of the composite prices per barrel of both domestic and foreign oil it was necessary to take into account the changing proportion of imported crude in the total input of crude of the U.S. refineries. This proportion which was about $12 \%$ in 1958 and $13 \%$ in 1963 declined to $11 \%$ in 1967 , but rose to $19 \%$ in 1972 . In 1973 and 1974 it was approximately $26 \%$ and $29 \%$, respectively. In 1975 the percentage rose to $33 \%$ and in 1976 to $39 \%$, underscoring an increasing reliance of this country on foreign oil.

The sharp-rising share of foreign crude in the total input of refineries combined with the sharply rising prices of such crude and their upward pressure on domestic prices of crude is the basic story of oil in the 1973-1976 period.

Movements of crude prices in the years under consideration were generally accompanied by concommitant movements in prices of refined products, with price controls exercising a moderating influence on their advance.

Although refined product price levels are not very closely related to prices of crude, they could be expected to reflect, among other factors, the cost of the most important single input. The cost of crude (excluding cost of delivery) to refineries in 1972 represented about $71 \%$ of the F.O.B. price of refined products; in 1973 about $69 \%$

If Although the fact that prices of imported cruae were lower than those of domestic crude during the period when import quotas were in operation is well known, it is not surprising that both imported and domestic crude were carried on the books of U.S. refiners (acquisitions costs) at about the then prevailing higher domestic prices. 
and in 1974 about 75\%. In 1975 the cost of crude to.refineries approximated $79 \%$ and in 1976 - 76\%. In 1958 and 1963 this proportion was close to $70 \%$ and in 1967 about $66 \%$.

As can be seen in Table 5, the annual average price of a barrel of refined products including taxes which stood at $\$ 4.93$ in 1958 edged down to $\$ 4.89$ in 1963. In the subsequent census years, 1967 and 1972, the price per barrel was higher over the preceding census years by 25 cents and 39 cents, respectively. From $\$ 5.53$ in 1972 the price jumped by $19.3 \%$ to $\$ 6.60$ in 1973 , with most of the increase taking place in the last quarter of the year as price controls on refined products were relaxed to permit refiners to pass along at least in part the increased costs on gasoline, home heating and diesel fuels. In 1974, refined products made a very large gain of $79.2 \%$ reaching a level of $\$ 11.83$. This increase, while sizable, was still controlled. In 1975 the advance in price was on ly 9.0\% but still smaller than that in crude oil. In 1976 the price increase was $9.3 \%$, significantly greater than that of $6 \%$ in crude oil.

On the end-use ievel, prices of petroleum products were on a steep uptrend in the period covered by the four census years. In 1958 the price of a barrel of petroleum products at this stage of operations was $\$ 8.88$. It rose steadily in the subsequent years, reaching in 1972 the level of $\$ 11.40$. As a matter of fact, the end-use prices increased percentage-wise in this period faster than the prices of petroleum products on the refinery level. In 1973 and 1974 the end-use prices rose at an accelerated rate. In 1973 the price moved up to $\$ 12.63$, a gain of $10.8 \%$ from the preceding year. In 1974 the price advanced sharply, by $43.2 \%$ to an average of $\$ 18.08$ for the year. During these two years, however, the rate of increase 
was not as rapid as that on the refinery level. was it due to a stricter enforcement of price controls on the end-use level or to some other reason? It is an interesting question to explore.

In the post-embargo years of 1975 and 1976, the end-use prices registered much smaller relative advances than in 1973 and 1974. In relation to prices on the refinery level for the same years, these increases were also smaller, particularly in 1976.

\section{TAXES}

Total estimated indirect taxes on petroleum products were on the rise during the period under consideration, advancing from $\$ 1.60$ per barrel in 1958 to $\$ 2.49$ in 1972. They increased to $\$ 2.52$ in 1973 and further to $\$ 2.56$ in 1974 . In relation to the average value of petroleum products, however, taxes per barrel, as can be seen in Table 6, showed a considerable decline in 1974, reflecting a sharp rise in petroleum products prices during this year and the fact that the levied taxes are mostly based on rates expressed in cents per gallon. In 1972 total indirect taxes per barrel of petroleum products - Federal and states - paid on the refinery and end-use levels represented nearly $28 \%$ of the average value of a barrel, excluding taxes, sold to ultimate consumers. After declining to approximately $25 \%$ in 1973, they were down to about $16 \%$ in 1974 . The decline in taxes was particularly great on the refinery level as they dropped from about $13 \%$ of the average value per barrel in 1973 to $7 \%$ in 1974. Taxes per barrel paid on the refinery level in the 1972-1974 period were less than half of the taxes paid on the marketers level (Table 5). I/

1/ The estimates of taxes used in this study are somewhat smaller than actual, although the most important are included in these estimates. Because of the difficulties involved in the estimation of severance taxes paid on crude oil to states and local taxes paid on the petroleum products, these taxes were not included in the totals. 


\section{Table 6}

Federal and State Taxes per Barrel as Percent of Average Value of Petroleum Products, Excluding Taxes

$\begin{array}{lcc} & \text { Refinery Level } & \text { End-use Level } \\ 1958 & 12.6 \% & 13.4 \% \\ 1963 & 18.1 & 14.7 \\ 1967 & 16.3 & 15.6 \\ 1972 & 16.4 & 17.6 \\ 1973 & 13.2 & 16.1 \\ 1974 & 7.0 & 11.0 \\ 1975 & 6.3 & 11.1 \\ 1976 & 5.7 & 10.9 \\ \text { Sources: Based on data } & \text { included in Table } 5 .\end{array}$
continued on the downward trend in 1975 and 1976, reflecting the fact that in the oil industry these taxes changed very little during these two years while prices made further gains although much smaller than in 1973-1974.1/. As can be seen in Table 6, indirect taxes as a percent of the average value of petroleum products on the refinery level declined from their peak of $18.1 \%$ in 1963 to $5.7 \%$ in 1976 . on the end-use level, this percentage, after reaching its peak of $17.6 \%$ in 1972, was down to $10.9 \%$ in 1976. These substantial decreases in the relative importance of indirect taxes in the average value of petroleum products can be of interest to policymakers when the influence of indirect taxation on inflation of oil prices is considered.

I/ On the end-use level taxes levied by some state and local governments are proportioned to prices which explains less pronounced downtrend on this level than on the refinery level. 
Changes in the Levels of Prices on the Three stages of Operations, 1973-1976

The temporal movements of prices, excluding taxes, in the three stages of operations in the 1973-1974 period produced annual advances in prices considerably greater than those in the preceding years. The price advances in absolute terms in 1973 and 1974 at the crude level were significantly smaller than on the refinery and end-use levels, clearly suggesting that the petroleum industry was able not only to pass the increases in crude prices to the other two stages of operations, but also to enlarge gross margins in absolute terms.

\section{Table 7}

Changes in Prices (excluding Taxes) of a Barrel of oil on the Wellhead Level (including Imports), the Refinery Level and the End-Use Level 1/

\begin{tabular}{lcrr} 
Years & Wellhead Level & Refinery Level & End-use Leve \\
\cline { 2 - 3 } & $\$+0.66$ & $\$+1.08$ & $\$+1.20$ \\
$1972-1973$ & $\$+4.29$ & $\$+5.23$ & $\$+5.41$ \\
$1973-1974$ & $\$+1.28$ & $\$+1.07$ & $\$+1.37$ \\
$1975-1976$ & $\$+0.58$ & $\$+1.21$ & $\$+0.78$
\end{tabular}

The effect of the differences in price increases on gross revenues of the petroleum industry at the three stages of operations in 1973 and 1974 is indicated by the fact that an increase of one dollar in prices per barrel was generating for the industry additional annual gross revenues of about $\$ 4.5$ billion (excluding imported petroleum products) in each of these two years.

In the years 1975-1976, year-to-year changes in prices on the three stages of operations in the oil industry were less consistent then in

1) Prices at the end-use level exclude indirect taxes paid on both the refinery level and the end-use level. 
the 1973-1974 period. In 1975 prices in absolute terms on the refinery level rose less than on both the wellhead (including imports) level and on the end-use level. In 1976 advances in the refinery prices were significantly greater than on the other two levels. As a result, the refiners who in 1975 absorbed a part of the price increase in crude, in 1976 were in a position to raise their gross margins substantially. The marketers' record on the contrary, showed in 1975 greater price increases than those registered by refiners and in 1976 significantly smaller. The shocks produced by considerable increases in prices of imported oil in 1973 and 1974 and much smaller increases in 1975-1976, put in motion forces that within the operating constraints of the industry had clearly unsettling effects on the price relationships between the three stages of operations of the oil industry.

Comparative Relative Changes in Prices on the Three Stages of operations

Table 8 summarizes succinctly the record of relative price changes in the three stages of operations in the petroleum industry. In addition to yearly price changes in the 1972-1976 period, the table provides information on price changes between the census years included in this study and on the two-year price changes for the embargo period of 19731974. 


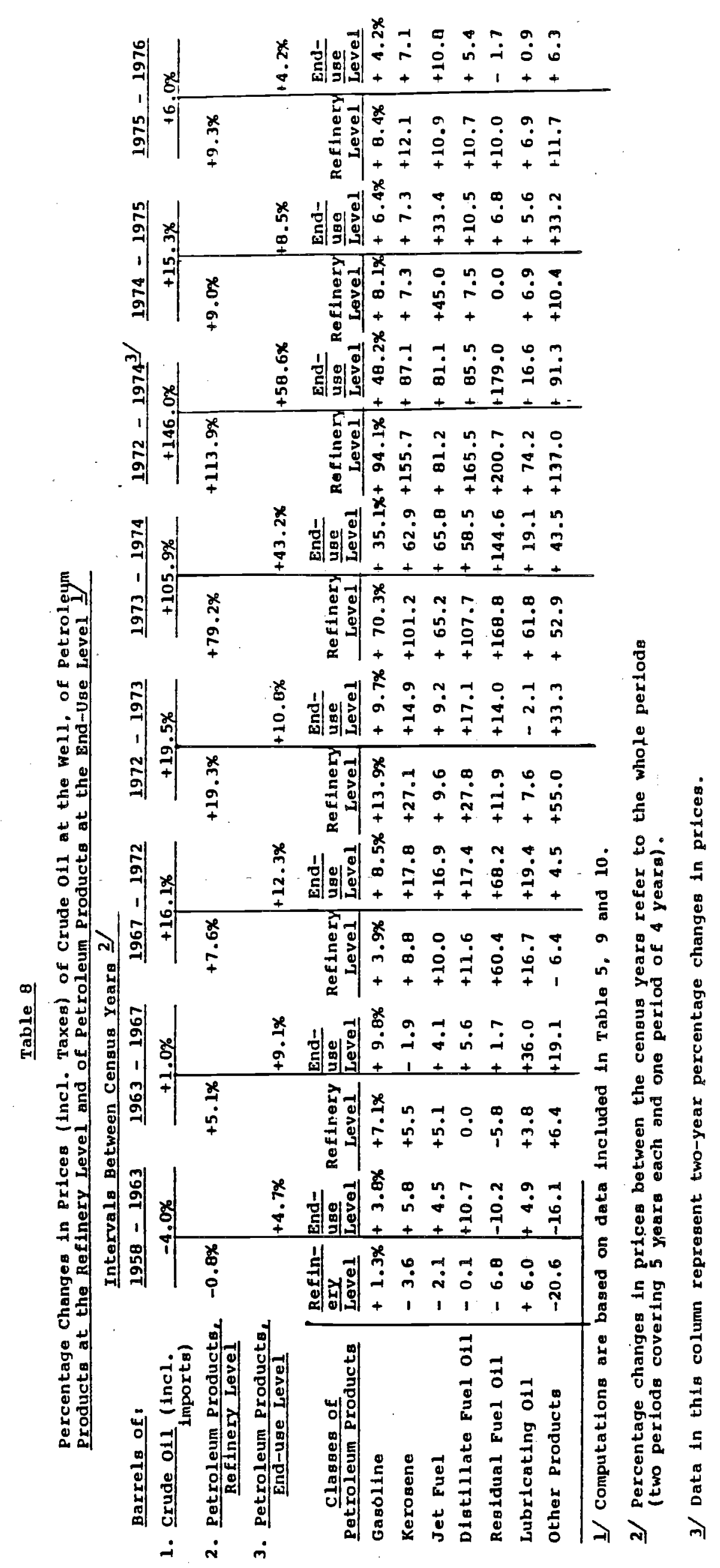


The largest two-year rate of increase in prices was registered by crude oil - 146.0\%; next in its importance was the rate of increase in prices of petroleum products at the refinery level - $113.9 \%$, and finally, the smallest rate of increase was exhibited by the refinery products on the end-use level - 58.6\%. This pattern of rising prices clearly implies that between 1972 and 1974 both the percentage margin of refiners - the difference between the selling price of refined products obtained from a barrel of crude minus the selling price of a barrel of crude divided by the latter - and that of marketers have undergone reductions, with the greater decline incurred by the marketers. It may be observed, however, that in 1973 the rate of advance in prices from the 1972 level was greater on the refinery level than the composite price of imported crude and domestic crude at the wellhead, suggesting some enlargement of the percentage margin. The marketers' percentage margin was down in 1973 and 1974.

In 1975 and 1976 oil prices advanced on all three stages of operations of the industry at much slower rates than in the preceding two-year period. However, the pattern of increases in 1975, which was similar to that in 1973 and 1974, showed a significant difference in 1976. In 1975 the year-to-year percentage increase in the price of a barrel of crude (15.3\%) was greater than that in the price of a barrel of refined products on a refinery level $(9.0 \%)$ and the year-to-year percentage price increase on the refinery level was somewhat greater than that on the end-use level (8.5\%). In 1976, however, the largest percentage price increase $(9.3 \%)$ was on the refinery level and the smallest one $(4.2 \%)$ on the end-use level. The rate of advance in crude oil (6.0\%), although greater than on the end-use level, was substantially smaller than on the refinery level. These changes in the price relationships between the three levels of operations in 1976 
cannot be ignored if an explanation is sought for the.significant changes that occurred in the oil industry's gross margins whether expressed in absolute terms or percentages (See Table II).

Although a barrel is used in this study as a standard for temporal and cross-section comparisons of the price levels in the oil industry, valuable information helping to understand the behavior of this aggregative measure is obtained when the behavior of the prices of the individual classes of products produced out of a barrel of crude and sold on the refinery level and disposed on the marketing level is also considered. Tables 9 and 10 given below contain price data underlying the computations presented in Table 8 . Moreover, they contain prices, excluding taxes (an important element in the structure of prices), which could provide an alternative basis for a study of the movements of prices through the petroleum industry. 
able 9

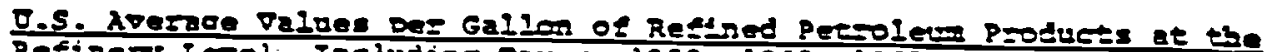

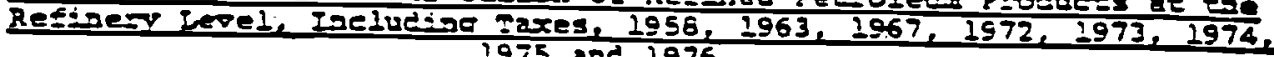
1975 and 1976

(centes per galloa)

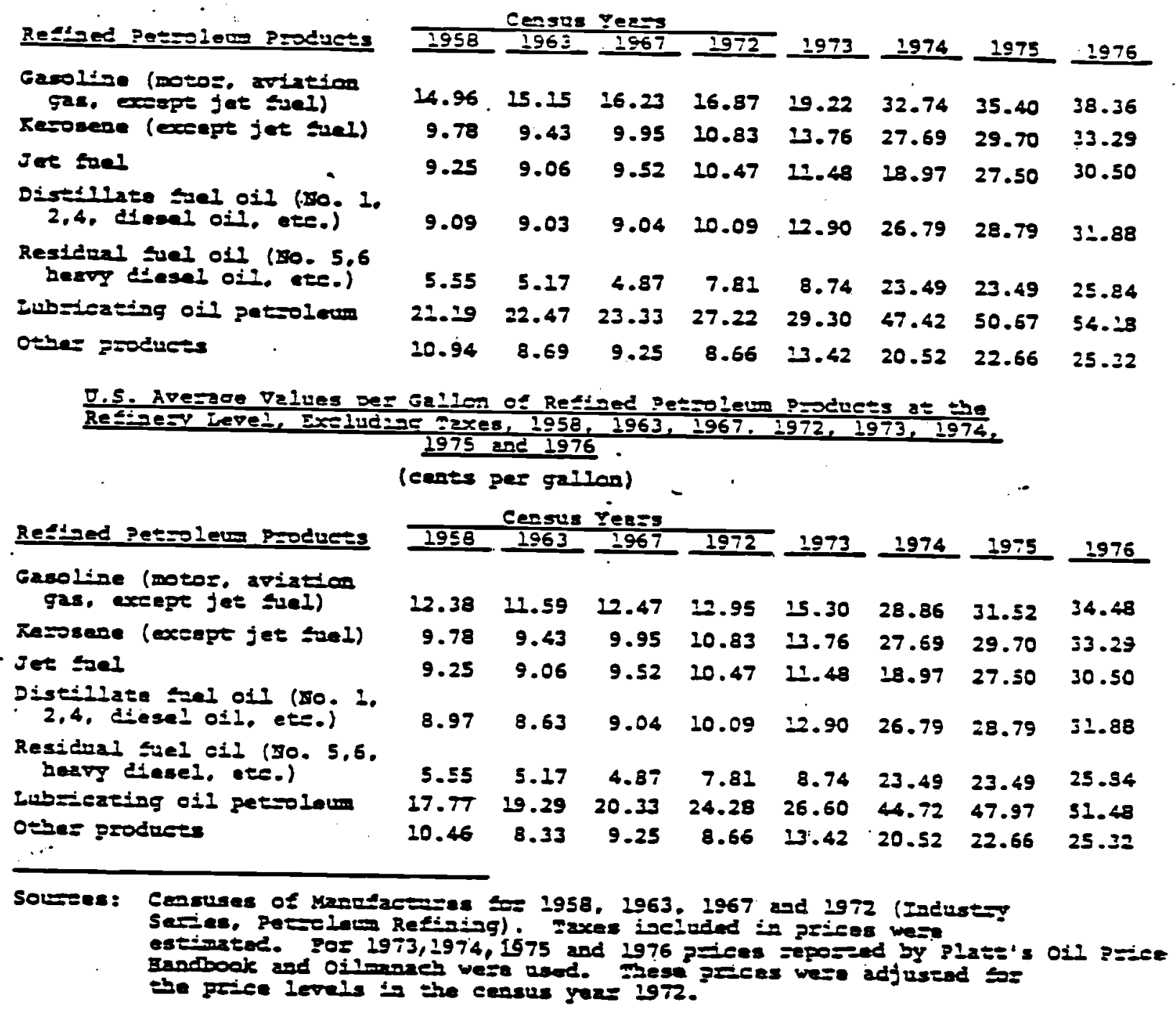




\section{Table 10}

O.S. Avezade Rerlized Pzices der Gallon of Refired Petzoleum Pooducss at the Enc-use Level, Includine Iaxes, 1958, 1963, 1962, 1972, 1973, 1974.1975 and 1976

(cents pe: gallon)

\begin{tabular}{|c|c|c|c|c|c|c|c|c|}
\hline \multirow[b]{2}{*}{ Resined petroleum p=oducts } & \multicolumn{4}{|c|}{ Cersus Years } & \multirow[b]{2}{*}{1973} & \multirow[b]{2}{*}{1974} & \multirow[b]{2}{*}{1975} & \multirow[b]{2}{*}{1976} \\
\hline & 1958 & 1963 & 1967 & 1972 & & & & \\
\hline $\begin{array}{l}\text { asolize (nots } \\
\text { gas. except }\end{array}$ & 29.39 & 30.51 & 33.49 & 36.25 & 39.88 & 53.88 & 57.33 & $\$ 9.73$ \\
\hline Rezosede (except jet fuel) & 15.24 & 16.12 & 16.09 & 18.96 & 21.78 & 35.47 & 38.06 & 40.78 \\
\hline Jet suel & 9.35 & 9.77 & 9.81 & 11.47 & 22.53 & 20.77 & 27.71 & 30.71 \\
\hline $\begin{array}{l}\text { istillate suel oil (No. } 1 \\
2,4 \text {, diesel oil, etc.). } \\
\text { esicual suel oil (No. } 5,6\end{array}$ & & 4 & 20 & 3.02 &. .27 & 35.29 & 38.99 & 41.08 \\
\hline 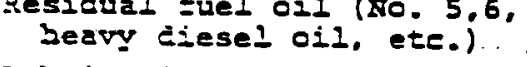 & 4 & 5.96 & 5.97 & 10.04 & 11.45 & 28.01 & 29.91 & 29.39 \\
\hline Lubricatisg oil & .01 .60 & 106.55 & 144.93 & 173.02 & 169.37 & 201.67 & 213.01 & 214.92 \\
\hline vtbe= produess & .23 & 9.42 & 11.22 & 21.73 & 15.64 & 22.44 & 29.90 & 31.79 \\
\hline
\end{tabular}

D.5. Avezare Realized Prices per Gallon of Refined Petzoleum produces It the End-use Level, Exeludine I 2xes, 1958, 1963, 1967, 1972, 1973, 1974,1975 anc 1976 -

(ceres per gailos)

Refined Petzoleum Products

Gasoline (motos, aviation sas. except jet frei)

. Rerosere (except jet fuel) je: suel

Distiliate Euel oil (No. I. 2.4. diesel oil. etc.)

Residual suel oil (צo. 5,6. beary diesel. ete.)

Iubrisating oil petoleum othez produes
Cersus Yez=s

\begin{tabular}{|c|c|c|c|c|c|c|c|}
\hline 1958 & 1963 & 1967 & 1972 & 1973 & 1994 & 1975 & 1976 \\
\hline 24.53 & 24.98 & 27.43 & 29.28 & 32.50 & 46.54 & 49.38 & 51.48 \\
\hline 14.61 & 15.40 & 95.47 & 18.26 & 20.85 & 34.04 & 36.54 & 39.15 \\
\hline 9.35 & 9.77 & 9.81 & 21.47 & 12.53 & 77 & 27.72 & 30.71 \\
\hline 13.16 & 14.22 & 14.63 & 16.59 & 19.55 & 32.15 & 35.51 & 37.46 \\
\hline 6.54 & 5.86 & .86 & 9.89 & 11 & 69 & 29.60 & 29.06 \\
\hline 101.60 & 06.55 & 44.93 & 173.02 & 169.37 & 201.67 & 213.01 & 214.92 \\
\hline 10.33 & 8.85 & 9.69 & 10.39 & 14.41 & 21.25 & 28.58 & 30.41 \\
\hline
\end{tabular}

Sources: Govement, indus $=Y$ and cossumers.

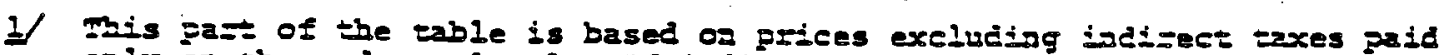

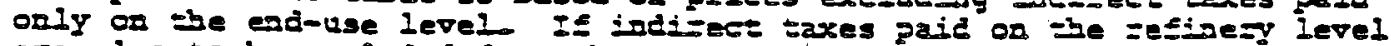
aje also to be excluded from these priess, the necessa-7 data cad be obraived som mable 9. 
Table 8 in its part based on individual classes of products shows that refinery prices of all product classes registered considerable, although quite uneven, gains in the 1972-1974 period, with some prices rising much faster than the composite price of the barrel of all product classes. The largest advance during these two years were made, when listed in the order of their importance, by "Residual fuel oil" (201\%). "Distillate fuel Oil" (165\%), "Kerosene" (156\%) and "Gasoline" $(94 \%)$. The "Other products" price was not included in this list because it was computed on the basis of only two classes of products, liquefied refinery gases and asphalt, and thus was less reliably estimated.

The unusually large increase in the price of residual fuel oil may be explained by a considerable expansion in demand for such oil by electric utilities (as a substitute fuel for natural gas and highsulfur bituminous coal) and quickened demand for shipping services as well as by the fact that the imported oil's proportion of this product in the total supply advanced to a level of $65 \%$ in 1973 and was still at $60 \%$ in 1974. As ail foreign petroleum products, the prices of residual oil increased sharply during these two years, pushing strongly upward the country's average price for this product.

A less rapid rise in prices was recorded by "Jet fuel" (81\%), and was mainly due to lagging prices. Since this product is sold predominantly on the basis of long-term contracts, many deliveries in 1973-1974 were made at prices lower than those that were then currently charged.

A smaller advance in prices was registered by "Lubricating oil" $(74 \%)$

It should $b \in$ noted that the largest increases in the refinery prices occurred in 1974 and under conditions of eased price controls. 
In 1975 and 1976, as in the preceding two-year period, prices of individual classes of refined products exhibited considerable diversity in their rates of change.

In 1975 - the year of mild winter and economic recession - the demand for petroleum products declined moderately below the 1974 level as decreases in the use of distillate oil, residual oil, liquid petroleum gases and asphalt more than offset an increase in the demand for motor gasoline (2\%). The year 1975 was characterized by a relaxation of controls on allocation and prices of such products as kerosene, distillate oil and residual oil.

The largest advance in refinery prices on the refinery level for the year was registered by jet fuel oil (45\%), reflecting a sharp rise in commercial kero-type jet fuel prices and the decline in their importance of lower old contractual prices in the average of actual prices paid during the year.

Residual oil prices showed no change from 1974, as production, on the uptrend since 1972, surged during the year and demand dropped by $8 \%$.

On the end-use level, prices of all classes of refined products recorded gains in 1975. As on the refinery level, jet fuel exhibited the greatest increase in prices (33.4\%). The smallest rise in prices (5.6\%) occurred in lubricating oil.

In 1976 the demand for refinery products was up (6.9\%), reflecting a moderate recovery of the economy and an unusually severe winter. Since production of crude, on the decline since 1970, was further down during the year, the increased demand as in the past was met through a greater import of both crude oil and refined products. I/

1 Domestic refineries in 1976 operated at $81.0 \%$ of operable capacity as compared with $81.7 \%$ in 1975 . 
On the refinery level, prices of all classes of refinery products, with the exception of lubricating oil, increased faster than prices of gasoline in 1976. The rates of advance in these products did not vary much and were in the range of $10 \%$ to $12.1 \%$. This compares with the gain of $8.4 \%$ for gasoline (in 1975 the rate of increase was about the same $-8.1 \%$ ).

On the end-use level prices of refined products on the average registered in 1976 the lowest rate of advance since $1972-4.2 \%$. The gain in gasoline prices for the year was also $4.2 \%$. Other price changes varied widely, with residual oil showing a decline of $1.7 \%$ and jet fuel an increase of $10.8 \%$.

The price upheaval of $1973-74$ in the oil markets led to a development whose importance cannot be underestimated. As a result of different rates of increase in prices of refined products, the differentials among prices of most classes of products long in existence, declined considerably in relative terms in 1974 (see Table 11). This phenomenon was found particularly pronounced when excise taxes were excluded from prices. The historical pattern in relationship to the prices of refined products, generally associated with the degree of lightness of the product (the lighter the product, the higher the price) while remaining basically little changed, showed also a somewhat narrower spread in the levels of actual prices of the major classes of products. 
rable 11

U.S. Averace Values Der Gallon of Refined Petroleum Products at the Refinezy Level, Including Taxes, 1958, 1963, 1967, 1972, 1973, 1974, 1975 and 1976

- Relation of Average values of Petroleum Products other than Gasoline to the Average Value of Gasoline -

(price of gasoline $=100)$

\begin{tabular}{|c|c|c|c|c|c|c|c|c|}
\hline Refined Petroleum Products & $\frac{c}{1958}$ & $\begin{array}{l}\text { ensus } \\
1963 \\
\end{array}$ & $\begin{array}{l}\text { Year } \\
1967 \\
\end{array}$ & s 1972 & 1973 & 1974 & 1975 & 1976 \\
\hline Gasoline & 100 & 100 & 100 & 100 & 100 & 100 & 100 & 100 \\
\hline Kerosene & 65 & 62 & 61 & 64 & 72 & 85 & 84 & 87 \\
\hline Jet fuel 1 & 62 & 60 & 59 & 62 & 60 & 58 & 78 & 80 \\
\hline Distillate fuel oil & 61 & 60 & 56 & 60 & 67 & 82 & 81 & 83 \\
\hline Residual fuel oil & 37 & 34 & 30 & 46 & 45 & 72 & 66 & 67 \\
\hline Lubricating oil & 142 & 148 & 144 & 161 & 152 & 145 & 143 & 141 \\
\hline Other products & 73 & 57 & 57 & 51 & 70 & 63 & 64 & 66 \\
\hline
\end{tabular}

U.S. Average Values per Gallon of Refined Petroleum products at the Refinery Level, Excluding Taxes, 1958, 1963, 1967, 1972, 1973, 1974, 1975 and 1976

- Relation of Average Values of Petroleun Products other than Gasoline to the Average Value of Gasoline -

Census Years

Refined Petroleum Products $\quad \underline{1958} \underline{1963} \underline{19671972} \quad 1973 \quad 1974 \quad 1975 \quad 1976$

$\begin{array}{lrrrrrrrr}\text { Gesoline } & 100 & 100 & 100 & 100 & 100 & 100 & 100 & 100 \\ \text { Kerosene } & 79 & 81 & 80 & 84 & 90 & 96 & 94 & 97 \\ \text { Jet fuel 1/ } & 75 & 78 & 76 & 81 & 75 & 66 & 87 & 88 \\ \text { Distillate fuel oil } & 72 & 74 & 72 & 78 & 84 & 93 & 91 & 92 \\ \text { Residual fuel oil } & 45 & 45 & 39 & 60 & 57 & 81 & 75 & 75 \\ \text { Lubicating oil petroleum } & 144 & 166 & 163 & 187 & 174 & 155 & 152 & 149 \\ \text { Other products } & 84 & 72 & 74 & 67 & 88 & 71 & 72 & 73\end{array}$

Source: Based on data included in Table 9.

If Computations are based mostly on realized contract prices winich were substantially lower than new prices in 1973 and 1974 . This accounts for a slower increase in the jet fuel prices during these years and the failure to show a decline in the differentials in 1973 and 1974. 
on the end-use level, prices of individual product classes showed less spectacular increases in the 1973-74 period, a fact that was reflected in the smaller advance in the price of a barrel of petroleum products on the end-use level, compared with the price of such barrel on the refinery level.

The largest gains by the product classes on the end-use level were registered, when listed in the order of importance, by "Residual fuel oil" (179\%), "Kerosene" (87\%), "Distillate fuel oil" (86\%), "Jet fuel" (81\%) and "Gasoline" (48\%). These increases altered somewhat the historical pattern in the relationship among the prices of most classes of products as well as the spread anong their actual prices on the end-use level. The price differentials among the products, considerably larger than those on the refinery level, in relative terms decreased in 1974, but less than on the refinery level (see Table 12).

In the 1975-1976 period, prices of individual refined products generally continued to rise at different rates on both the refinery and end-use levels, with their spreads showing a tendency toward further narrowing. The observed decline in differentials among prices was under way since 1973 and it is reasonable to interpret this development as a more than a passing change in the price structure of refined petroleum products. Within the framework of the regulatory conditions under which the oil industry was functioning the fact that prices of most of the refined products were allowed to advance faster than the price of gasoline (which was also on the rise), undoubtedly, contributed to the improvement in the profitability of the industry. 
Table 12

U.S. Average Realized Prices per Gallon of Refined Petroleum Produers at the End-use Level. Including Taxes, 1958, 1963. $1967,1972,1973,1974,1975$ and 1976

- Relation of Average Prices of Petzoleum Products other than Gasoline to the Average Price of Gasoline -

$$
\text { (Price of gasoline }=100)
$$

Refined Petroleum Products

Census Years

\begin{tabular}{lrrrrrrrrr}
\hline Gasoline & 100 & 100 & 100 & 100 & 100 & 100 & 100 & 100 \\
Kerosene & 52 & 53 & 48 & 52 & 55 & 66 & 66 & 68 \\
Jet fuel & 32 & 32 & 29 & 32 & 31 & 39 & 48 & 51 \\
Distillate fuel oil & 47 & 50 & 48 & 52 & 56 & 65 & 68 & 69 \\
Residual fuel oil & 23 & 20 & 18 & 28 & 29 & 52 & 52 & 49 \\
Iubricating oil & 346 & 349 & 433 & 476 & 425 & 374 & 372 & 360 \\
Other products & 38 & 31 & 34 & 32 & 39 & 42 & 52 & 53
\end{tabular}

U.S. Average Realized Prices per Gallon of Refined Petroleum Pzoducts at the End-use Level, Excluding Taxes, 1958, 1963. $1967,1972,1973,1974,1975$ and 1976

- Relation of Average Prices of Petroleum Products other tiran Gasoline to the Average Price of Gasoline -

$($ Price of gasoline $=100)$

Refined Petroleum Products

Census Years

Gasoline

1958196319671972

1973

1974

$1975 \quad 1976$

Kerosene

$\begin{array}{llll}100 & 100 \quad 100 \quad 100\end{array}$

100

100

$100 \quad 100$

Jet fuel

$\begin{array}{llll}60 & 62 & 56 & 62\end{array}$

64

73

7476

Distillate. fuel oil

$\begin{array}{llll}38 & 39 & 36 & 39\end{array}$

$\begin{array}{llll}54 & 57 & 53 & 57\end{array}$

$\begin{array}{llll}27 & 23 & 21 & 34\end{array}$

Residual suel oil

$\begin{array}{llll}414 & 427 & 528 & 593\end{array}$

other products

$\begin{array}{llll}42 & 35 & 35 & 36\end{array}$

60

$45 \quad 56$

60

$\begin{array}{llll}35 & 59 & 60 & 56\end{array}$

$\begin{array}{llll}521 & 433 & 431 & 417\end{array}$

Sources: Based on data included in Table 10. 
The Effect of Cross-section Movements of Prices on Gross Marqins

The data and comments presented above provide a useful background for the examination of the cross-section movements of prices through the three stages of operations of the petroleum industry for their effect on margins, although some passing remarks on this subject were already made in another context.

Table 13 shows that the refiners' gross margin -- the difference between the F.O.B. price of a barrel of petroleum products and the F.O.B. composite price of a barrel of domestic and foreign crude, excluding taxes -- which was $\$ 1.36$ in 1972, expanded to $\$ 1.78$ in 1973 and further to $\$ 2.72$ in 1974 . These increases in the margin meant aditional gross receipts for the refiners of about $\$ 1.9$ billion in 1974. The rargin as defined here includes the costs of transportation of crude to refineries, other costs and profit (if any) and actually is the price of the refining function plus transportation costs. The census data for 1972 indicate that the average transportation costs per barrel of crude from the wells to refineries in the U.S. for that year were 25c. One oil industry source estimated these costs for 1973 at $25 \mathrm{c}$ and for 1974 at $30 \mathrm{c}$. Table 13 also gives the refiners' margin for the census years of 1958, 1963 and 1967, which was \$1.37, \$1.25 and $\$ 1.50$ in the respective years.1/ These data suggest no clear trend in the margin in the $1958-72$ period. It is well known, however, that the margin is sensitive to cyclical influences. $2 /$

I/ Refiners' margins net of transportation costs were estimated to be in:
$1958-\$ 1.07$
$1963-\$ 1.05$
1972 - \$1.11
$1967-\$ 1.30$
$1973-\$ 1.53$
$1974-\$ 2.42$

2/ Competition in Oil, Daniel C. Hamilton, Harvard University Press, 


\section{Table 13}

Average Gross Margins on a Barrel of Petroleum Products 1 /

\begin{tabular}{|c|c|c|}
\hline & $s$ & $\%$ of Price \\
\hline 1958 & $\$ 1.37$ & $45.5 \%$ \\
\hline 1963 & 1.25 & 43.3 \\
\hline 1967 & 1.50 & 51.4 \\
\hline 1972 & 1.36 & 40.1 \\
\hline 1973 & 1.78 & 44.0 \\
\hline 1974 & 2.72 & 32.6 \\
\hline 1975 & 2.51 & 26.1 \\
\hline 1976 & 3.14 & 30.8 \\
\hline
\end{tabular}

$\frac{\text { Refiners' Margin }}{\text { (Excl. Taxes) }}$

$\$$ \% of Price
Marketers' Margin (Excl. Taxes)

\begin{tabular}{|c|c|}
\hline$\underline{s}$ & $\%$ of Price \\
\hline$\$ 2.90$ & $66.2 \%$ \\
\hline 3.22 & 77.8 \\
\hline 3.64 & 82.4 \\
\hline 4.16 & 87.6 \\
\hline 4.28 & 73.4 \\
\hline 4.46 & 40.3 \\
\hline 4.76 & 39.2 \\
\hline 4.34 & 32.5 \\
\hline
\end{tabular}

1 Computations are based on data included in Table 5. 
The marketers' margin on the costs of moving a barrel of petroleum products from the refineries through the distribution channels to the ultimate consumers (the marketers' function), excluding taxes, was $\$ 4.16$ in $1972.1 /$ This margin advanced to $\$ 4.28$ in 1973 and $\$ 4.46$ in 1974. The gains in margins in these two years, much smaller than for refiners, brought to the marketers also much smaller additional gross receipts: about $\$ 545 \mathrm{million}$ in 1973 and about $\$ 795$ million in $1974.2 /$ In the census years of 1958, 1963 and 1967 the margin was $\$ 2.90, \$ 3.22$ and $\$ 3.64$, respectively. The marketers' margin was on the uptrend during the whole period considered in this study. The most striking feature of the marketers' margin is its size. In 1974, the cost of processing a barrel of petroleum products amounted to $\$ 2.42$ (refiners' margin minus transportation costs) while the distribution costs of the same barrel were $\$ 4.46$.

In the 1975-1976 period, gross margins of the industry exhibited significant deviations from their trend.

On the refinery level the refiners' margin, on the rise since 1963. decreased from its peak level of $\$ 2.72$ per barrel in 1974 to $\$ 2.51$ in 1975. In 1976, however, it moved up to a new high of $\$ 3.14$.

On the end-use level the marketers' margin per barrel continued on the uptrend in 1975, reaching a high of $\$ 4.76$ in that year. In 1976 . however, it was down to $\$ 4.34$.

Any attempt to provide an adequate explanation of these changes in the industry's margins would require a detailed analysis of the elements of costs on the refinery and end-use levels. The pertinent information If Taxes excluded are indirect taxes paid on both the refinery and end-use
levels.

2/ The quantities of petroleum products underlying the computation of these amounts do not include imported petroleum products. 
for this, unfortunately, is not made available by the companies for public use. The fragmentary general industry data, however, suggest that marked fluctuations in weather and general economic activity as well as changes in regulatory conditions in the 1975-1976 period had a notable but uneven effect on the supply and demand and prices of individual products, with the corresponding impact on the industry's gross margins. The clear example of this is the failure of residual oil prices to advance on the refinery level in 1975 and a small decline of these prices on the end-use level in 1976 while prices of other products continued to increase.

It is interesting to note that the oil industry's gross margins in relation to prices on the refinery level showed a declining trend in the 1973-1976 period. The similar trend can be observed on the end-use level in the 1972-1976 period. The existence of these trends is not accidental. It can be attributed to the failure of some components of costs to increase proportionately with the increase in crude, the largest component of total costs of refined products. If From the sketchy discussion of the marketing operations presented earlier and the fact that the cost of marketing (excluding the cost of crude oil) is the largest component of the price of refined products paid by final consumers, it is clear that any anti-inflationary policy in order to be effective must consider not only the total price of the marketing function, but also the cost of it on various levels of distribution. By locating in time an unusual rise in prices on the intermediary levels of distribution a basis is provided for anti-inflationary

I/ The distributors' margins and costs of transportation generally do not vary proportionately with the cost of crude. 
actions, if this would be found justified. This problem does not arise on the refinery level, because crude generally moves from the wellhead to refineries without intermediaries.

It is important to stress that in the oil industry what counts is the absolute size of the margin and not the percentage margin or markup. a concept that is widely used in the industry and commerce. As a matter of fact, when prices rose sharply in 1974, the percentage margin declined considerably on the refinery level and the marketing level, while the margin in absolute terms showed substantial enlargement. A proportional increase in the margin would have meant an enormous rise in profit. Historically, it is the concept of a margin in absolute terms that has been in use in the industry.

\section{Petroleum Prices, Other Prices and Profits}

The price explosion of 1973-1974 in the oil industry coincided in time with the acceleration in the rate of inflation in this country and thus could only aggravate the corrosive influence of the rapidly rising general price level on the American economy.

The principal annual price indexes presented below, however, do not reflect clearly and consistently the strong advances in prices of petroleum products, representing on the end-use level a mixture of wholesale and retail prices. 


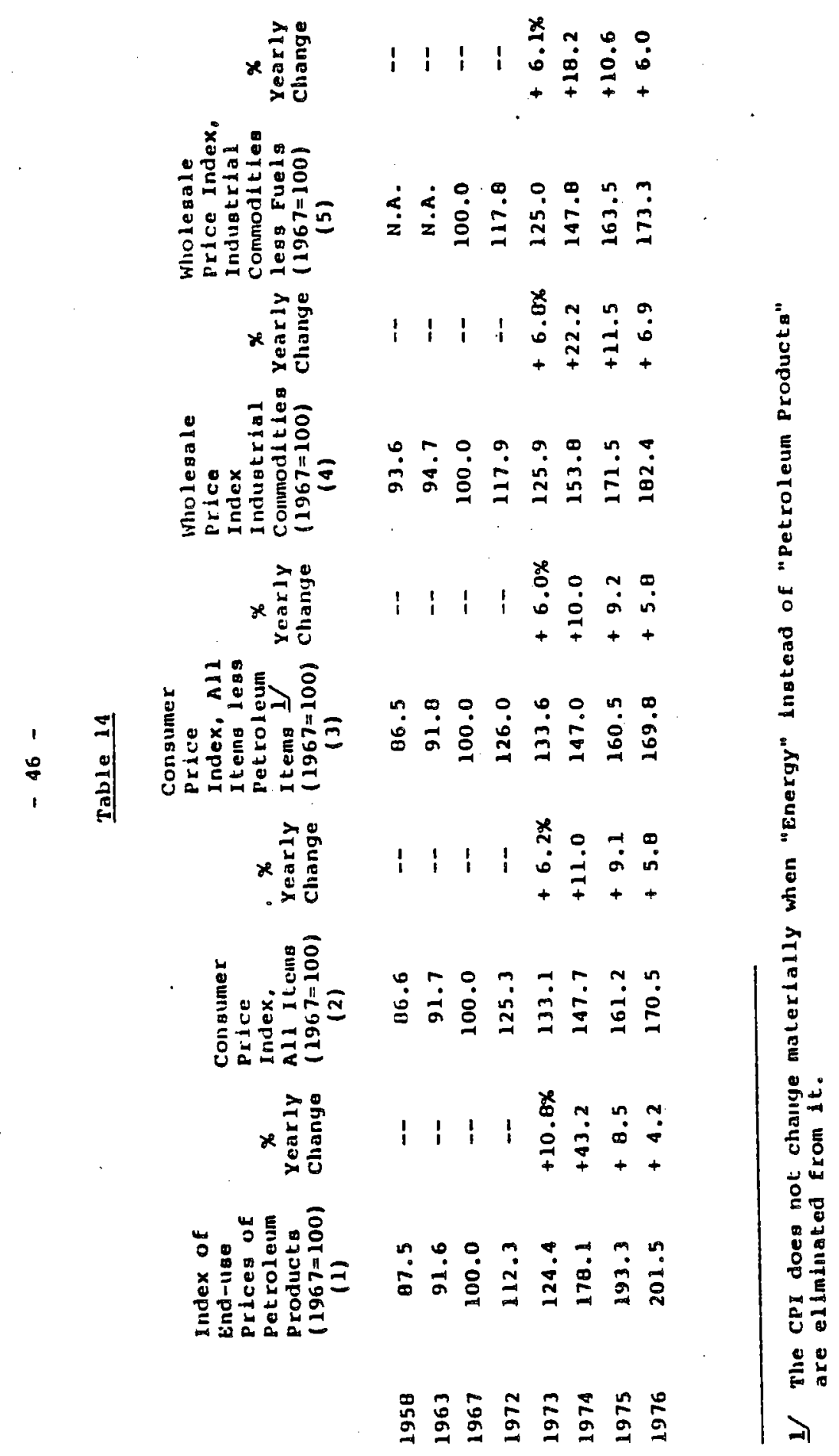


As can be seen in Table 14 the consumer Price Index, All Items (CPI) and the Consumer Price Index, All Items, Less Petroleum Items rose at about the same rate - 6\% - in 1973. In 1974, the advarce in CPI from the 1973 level was $11 \%$ or 1\% faster than in CPI, Less Petroleum Items. On the wholesale level, the price index of industrial commodities (WPI, IC) including "Fuels" in 1973 and 1974 showed significantly more rapid increases than the same index, excluding "Fuels".

In the post-embargo years of 1975 and 1976 the consumer price index with and without petroleum items advanced at a declining rate, but in each of these two years the rates of change virtually did not differ from each other. The WPI, IC including "Fuels" and WPI, IC excluding "Fuels" during these two years exhibited much smaller discrepancies in their rates of advance than in 1974. These discrepancies were close to that in 1973 .

The observed differences in impact of rising oil prices on the general price indexes reflect not only changes in prices of refined products but also the fact that: (1) "Petroleum Items" in the CPI have a weight of about. $4.5 \%$ and "Fuels" in the WPI, IC - $10.4 \%$; the CPI is composed of prices of goods and services and WPI - of prices of goods only; and, finally, (3) the bulk of petroleum products sold at retail prices (for instance, gasoline) exhibited smaller rates of increase than the bulk of petroleum products sold to the ultimate consumers at wholesale prices (for instance, residual fuel oil) in the 1973-1974 period.

The simple comparison of the indexes obviously does not allow the taking into account fully of the direct and indirect effects of the increases in prices of petroleum products on these indexes, some of which may be expected to be felt with a certain time lag, particularly under conditions of price controls. In special situations these effects 
were quite substantial as it is exemplified by a strong upward thrust in the electricity rates due to higher prices of fuels.

It may be observed that the CPI and WPI, IC made greater annual gains than prices of petroleum products on the end-use level in the 1967-1972 period. The reverse was true in the two subsequent years of 1973 and 1974. In 1975 and 1976 CPI and WPI showed again larger yearly advances than those registered by the end-use prices of petroleum products.

The sharp increases in prices of crude oil and petroleum products in 1973 and 1974 produced substantial advances in net income of the petroleum industry during these two years. In 1975 net income was about the same as in the preceding year, but moved up strongly in 1976. The full import of these changes, however, is not easy to assess because of the usual limitations of the accounting data available for public use. The published annual reports of the petroleum companies, however, can still serve as a reasonable basis for statements of at least indicative value on the profit performance of the oil industry. Two most often used annual profit rate series for the petroleum industry developed on the basis of the reports were selected for this purpose. These series are: (1) Citibank's "net income after taxes on net worth" of leading petroleum corporations (with net worth on January 1), and (2) Chase's net income after taxes on "average invested capital" (includes preferred stock, common stock and surplus, as reported on December 31). The behavior of the two series in 1967-1976, a period considered long enough to provide a perspective on the developments in 1973 and 1974, was found, generally, to be quite similar despite 
the differences in coverage, definitions and accounting. 1

Table 15

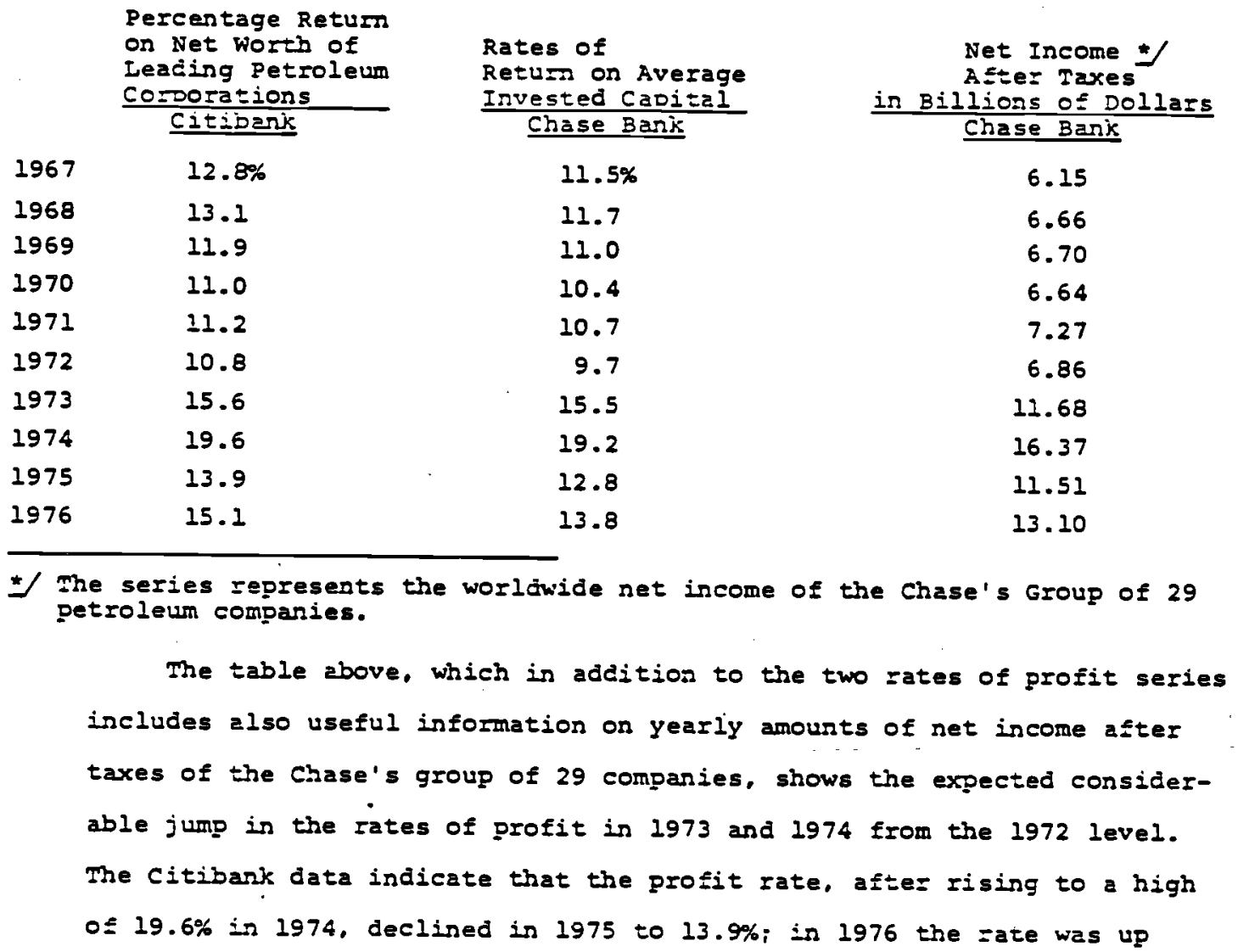

1 The yearly number of the leading petroleum corporations included in the Citibank's series varied from 91 to 108 in the $1967-1976$ period. The Chase's series are based on the analysis of the financial performance of the 29 largest petroleum companies. This group of companies, according to Chase's Energy Economic Division. "provides a valuable basis for determining the probable experience of the overall industry." "1976 Financial Analysis of a Group of Petroleum Companies". by Richard 5 . Dobias and Nozma I. Anderson. Chase, October 1977. 
again, to $15.1 \%$. The chase shows for the corresponding two postembargo years profit rates of $12.8 \%$ and $13.8 \%$. I/

The Chase's supplementary data published in the yearly "Financial Analysis of Group of Petroleum Companies", although highly aggregative, throws some additional light on the profitability of the petroleum industry in 1973 and 1974. Annual after taxes net income changes of the Group, which did not exceed $10 \%$ in the 1967-1972 period, jumped by $70 \%$ to $\$ 11.7$ billion in 1973 and further by $40 \%$ to $\$ 16.4$ billion in 1974. These sharp advances in eanings were accompanied by a rise in the proportion of retained net income from $45 \%$ in 1972 to $65 \%$ in 1973 and to $71 \%$ in 1974. As a result, net worth of the group increased by $11 \%$ in 1973 and by $15 \%$ in 1974 , much faster than in any year of the 1967-1972 period. This unusual expansion of net worth due to unusual increases in retained income had for its effect to slow down the rise in the rates of profit of the group in 1973 and 1974. It should be also noted that despite the fact that ret income after taxes of the Chase's group of oil companies was virtually the same in 1973 and 1975; the group's rates of profit for these two years differed considerably - in 1973 the profit rate was $15.5 \%$ and in 1975 $12.8 \%$ - obviously, due to the difference in the levels of net worth. Whether or not the ratio of net income to net worth adequately measures the profitability of the oil industry (other measures of profitability have also their shortcomings), its levels in the 1973-1976 period were above those that were recorded between 1951 and 1973 as they reflected an extraordinary upsurge of net income in this period.

1/ The repeal of depletion allowances (effective as of December 31, 1974). undoubtedly was a factor affecting the reported income of the petroleum companies in 1975 and 1976. 
The Chase's "Financial Analysis of a Group of Petroleum companies" attributes the rise in net income in 1973 to: (1) the devaluation of the dollar; (2) inventory profits due to... "Petroleum price increases initiated by government"... and (3) the recovery of chemical and shipping activities.

In the "Financial Analysis" for 1974, the Chase writes on page 9, "The large crude oil prices increases dictated by the governments of several foreign producing countries in 1974 necessitated a substantial rise in prices of petroleum products." And further, on page 12, it states: "Along with other significant increases recorded on the group's income statement, net income also grew, but to a much lesser extent." "...More than one-quarter of the gain reflected inventory profits early in the year that were the result of the dictated change in the price of crude oil. Arother important factor in the earnings rise was the substantially large contribution made by the chemical activities." It may be observed, however, that sales of chemical products accounted for only $6.5 \%$ of the operating revenue of the Group in 1974 . The annual reports of the petroleum companies, regrettably, do not contain information on net income steming from domestic activities related to production of crude, refining and marketing separately. They also do not provide detailed information on costs of these activities. And although it is not possible to estimate directly whether or not there were significant increases in profit on each of the three stages of operations of the petroleum industry in the united states in 1973 and 1974, the sharp increases in prices of crude and petroleum products, the noticeable widening of the refinery and marketers' margins and the extraordinary rises in the aggregate net income in the two years under consideration indirectly suggest that these developments are not incompatible with the notion that such increases in profit did occur in 1973 and 1974. 
$-52-$

A rough measure of the oil industry's profitability is also provided by net income after taxes per barrel of mazketed refined products. The table below contains the relevant data for the 19671976 period.

\section{Table 16}

\begin{tabular}{c} 
U.s. \\
Crude oil \\
Production \\
(Mhousand \\
barrels \\
per dav) \\
\hline
\end{tabular}

(1)

\begin{tabular}{l} 
U.S. \\
Crude oil \\
Refinery \\
Runs \\
(Thousand \\
barrels \\
Der dav) \\
\hline
\end{tabular}

$$
\text { U.S. }
$$
Demand for Petroleum Products (Thousand) barrels Der dav) $(1967=100)$

(2)

(3)

(4)

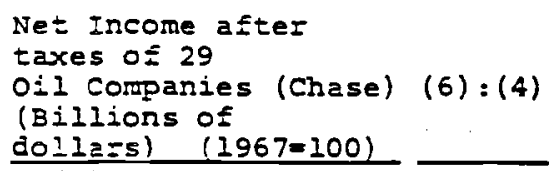

$$
9,815
$$

12,560

$100.0 \%$

19689,096

10,312

13,393

106.6

(5)

(6)

$$
10,629
$$

14,137

112.6

$1970 \quad 9,637$

10,870

14,697

117.0

6.15

$100.0 \%$

$100.0 \%$

19719.463

$$
11,200
$$

15,213

121.1

i2, 696

16.367

130.3

6.66

108.3

101.6

6.70

108.9

86.7

6.64

108.0

92.3

7.27

118.2

97.6

19739,208

$$
12.431
$$

17.308

6.86

111.5

85.6

$1974 \quad 8.774$

$$
12.133
$$

16.653

137.8

11.68

189.9

137.8

12,442

16,322

132.6

16.37

266.2

200.8

1976

8.119

13.416

17.443

130.0

11.51

187.2

144.0

13.10

213.0

153.3

Sources: U.S. Department of the Interior, Bureau of Mines, and "Financial Analysis of Group of Petroleum Companies", Chase.

The colun (7) in the table above clearly indicates that, winen tine index of net incore of the Chase's Group is divided by the index of all petrolew products marketed in the united states, there was an encmous Iise in profit per barrel of sucin products in 1973 and 1974. obviously. this result has only indicative value since net income of the petroleun comparies is a product of various activities, some of which are not directly related to production and sales of crude oil and petroleum products in the united states. The net income series reflected mainly: (1) a decline is domestic production of crude observed since 1970 (colurn 1); (2) an increased use of foreign crude in lefining operations 
(column 2): (3) an increased importation of petroleum products in 1973. but a reduction of such importation in 1974 as total demand for oil products aropped; (4) various foreign operations; inventory profits due to higher prices, and (6) very large advances in prices of foreign crude and petroleum products and much smaller advances in domestic oil prices. It should be noted that operating revenues other than crude oil and refined products accounted for only about $15 \%$ of the total operating revenue of the group in 1973 and 1974.

In the post-embargo years of 1975 and 1976 net income after taxes per barrel of marketed products showed increasingly higher levels in reiation to 1973, but it was still below its all-time high in 1974. The gains in these two years took place despite the decline of the refiners' margins in 1975 and the marketers' margins in 1976.

\section{Summary and Conclusions}

1. The study of propagation of prices in the petroleum industry in the 1972-76 period is the main objective of this report. Unfortunately, price data necessary to achieve this objective are not readily available. While national averages of crude prices (rather average values of crude) are directly provided by the Bureau of Mines, the estimation of petroleum product prices at the refinery level had to be made through the liberal use of census data for the census years (a largely neglected source in this respect) and the selected representative prices of individual products for the product classes adjusted for the level of prices in the closest census year for 1973 , 1974, 1975 and 1976. The prices on the end-use level were collected from all accessible sources: government, industry and consumers. 
Because of lack of consistent and reliable data on a monthly basis, the analysis in this study was carried out on the basis of annual data.

2. A 42-gallon barrel was used as a yardstick for the estimation of prices on the three major stages of operations in the industry. namely, (1) prices of crude at the wellhead (including imports), (2) prices of petroleum products at the refinery level, and (3) prices of petroleum products on the end-use level. The set of data obtained, despite its limitations, can serve various purposes. The estimated prices on the three stages of operations provides a basis for the computation of the total value of sales on each stage. For example, the cost of refined products to ultimate consumers was estimated to approximate $\$ 71$ billion in 1973 and $\$ 101$ billion in 1974. This type of information, when related to other variables, can be of value in the economic analysis. Obviously, this set of data also provides a basis for the study of temporal and cross-section changes in prices.

3. Prices of crude, after a decline in 1958, moved in a narrow range in the 1959-1967 period. From 1967 to 1976 prices were on the uptrend, with the largest increase registered in 1973 and 1974. Prices of refined petroleum products generally followed the movements of crude prices exhibiting sometimes smaller, sometimes larger absolute and relative changes by comparison with the prices of crude in the 1958-1972 period. In 1973 prices of petroleum products advanced at about the same rate as those of crude, but showed a significantly slower rate of rise in 1974. In both these years -1973 and 1974 - absolute increases in prices on the refinery level were substantially greater than prices on the wellhead level. 
On the end-use level, prices of petroleum products were on a steep uptrend - in absolute and relative terms - in the period covered by the four census years. They also advanced at a more rapid rate than prices on the refinery level during this period. In 1973 and 1974 end-use prices of petroleum products rose at an accelerated rate. This rate, however, was not as fast as that of prices on the refinery level, although it still produced somewhat greater increases in absolute terms.

In 1975 prices in absolute terms on the refinery level rose less than on both the wellhead (including imports) level and on the end-use level. In 1976 advances in the refinery prices on the refinery level were significantly greater than on the other two levels. As a result, the refiners, who in 1975 absorbed a part of the price increase in crude, in 1976 were able to expand their gross margin substantially. The marketers' record in 1975 showed a greater price increase than that registered by refiners. In 1976 the price increase was significantly smaller.

The shocks produced by considerable increases in prices of imported oil in 1973 and 1974, and much smaller increases in 19751976. put in motion forces that within the operating constraints of the industry had clearly unsettling effects on the price relationships between the three stages of operations of the oil industry.

The price changes on the three stages of operations in 19731974 suggest that the petroleum industry was able during these two years not only to pass the unusual increases in crude prices to the other two stages of operations, but also to enlarge them significantly. In the post-embargo years 1975-1976, year-to-year changes in prices on the three stages of operations in the oil industry were less consistent than in the 1973-1974 period. The differences in behavior 
on the three stages of operations can be largely explained by the structure of the petroleum industry, the special forces that operated on each of these stages and the varying application of price controls.

4. An important development took place on the level of prices for individual classes of petroleum products in the 1973-1976 period. Although some of these prices advanced faster than the others on both the refineries and marketers' stages of operations, prices of products generally moved closer to gasoline prices, reducing considerably in relative terms the differentials among them. The decline in differentials was particularly pronounced on the refineries' stage of operations. The implication of this development is that the narrowing of the price spread during the period under consideration was a factor in the improved profit performance of the oil industry.

5. Refiners' gross margins in absolute terms, generally exhibited small changes with no trend in the 1958-72 period. They showed considerable increases in 1973 and 1974. In 1975 the margins declined, only to rise to their all-time high level in 1976. The percentage margins or mark-ups were characterized by the same behavior in the 1958-72 period, but after increasing in 1973, declined markedly in 1974. The percentage was down again in 1975. In 1976 it rose, but was still below the level reached in 1974.

The marketers' gross margins in absolute terms except for 1976 were on the rise during all of the period under consideration in this study. They showed, however, substantially smaller increases in 1973 and 1974 than the refiners' margins in these two years. In 1975 the marketers' margins were up while those of refiners were down. The reverse was true in 1976. The percentage margins or mark-ups were on the rise from 1958 through 1972, but were sharply down in 1973 
and 1974. They decreased further in 1975 and 1976. The failure of many components of refined products costs to increase proportionately with the increase in costs of crude (the largest component of total costs) along with the varying degree of strictness with which price controls were applied on the refinery level and the end-use level could largely account for the difference in the margin's behavior on these two levels in 1973-1976.

6. Although petroleum prices made considerable advances in the 1973-1976 period, the general price indexes, except the WPI, failed to reflect them noticeably. With price controls in operation, the inflationary effects of these advances, however, could have been expected to be felt with certain lag. In special situations these effects were quite strong as it is exemplified by a substantial rise in electricity rates due mainly to higher prices of fuels.

7. The price explosion in the oil industry in 1973 and 1974 and more moderate price increases in 1975 and 1976 were accompanied by an upsurge in the profitability of the industry.

Net income after taxes of the 29 largest petroleum companies (the Chase Bank sample), which was at the level of $\$ 6.9$ billion in 1972. jumped to $\$ 11.7$ billion in 1973. It climbed to its all-time high of $\$ 16.4$ billion in 1974, but decreased to $\$ 11.5$ billion in 1975. Net income resumed its advance in 1976, reaching a level of $\$ 13.1$ billion for the year.

When profitability of the oil industry is measured by the ratio of net income after taxes to net worth, the reported ratios show levels in 1973 and 1974 significantly above those that prevailed in the 1952-1972 period. The profit rates in these two years would have been even markedly higher if there were no unusual increases in 
net worth, due to the unusual increases in retained earnings.I/ It should be also noted that despite the fact that net income after taxes of the Chase's group of oil companies was virtually the same in 1973 and 1975, the group's rates of profit for these two years differed considerably - in 1973 the profit rate was $15.5 \%$ and in 1975 - $12.8 \%$ - obviously, due to the difference in the levels of net worth.

A rough measure of the oil industry's profitability is also provided by net income arter taxes per barrel of marketed refined products.

Net income after taxes per barrel of refined oil products consumed in the United states, after rising considerably in 1973 and 1974, in 1975 and 1976 was significantly below its extraordinary level of 1974, but still higher than in 1973. It should be noted that despite the fact that the volume of net income after taxes in 1975 was slightly lower than in 1973, such income per barrel of oil products consumed was higher in that year (Table 16) and continued

1) A meaningful evaluation of the profitability of the industry should take into account not only the behavior of the net worth variable over time but also many other factors, including the fact that to the extent that the oil industry is investing in reserves of fuel other than oil such as coal, uranium, oil shale and timberland (and the industry's holdings of these reserves are considerable and increasing) and does not exploit them, it is in possession of assets which do not currently yield profit but whose potential profit increases inexorably. with the rising value of the reserves. 
to advance in 1976. The increases of income per barrel of oil in the 1973-1976 period occurred despite the considerable and systematic yearly decreases in production of domestic crude oil which, after reaching a peak of 9.64 million barrels per day in 1970, dropped to a level of 9.21 million in 1973 and then to 8.12 million in 1976 or down by 1.1 million barrels per day in the $1973-1976$ period.I/ It may be also observed that if there were no elimination of depletion allowances at the end of 1974, income per barrel of oil products in 1975 and 1976 obviously would have been significantly higher than it was in these two years. A more rapid rise in prices of refined products other than gasoline was a factor contributing to the excellent over-all performance of the oil industry in the 1973-1976 period. The unavailability of the necessary accounting data makes it impossible to estimate directly whether or not there were significant increases in profit on the barrel basis on the three stages of operations of the petroleum industry in the United States in 1973 and 1974. However, such developments in these two years as the extraordinary rises in the aggregate net income, the sharp increases in prices of crude and petroleum products and the marked widening of the refinery and marketers' margins, when taken together directly suggest that they are not incompatible with the notion that increases in profit on the barrel basis did occur on each of the three stages operations of the industry.

1/ The decline in domestic production of crude took place in a period when "new oil" could be marketed at the high world prices established by OPEC. The existence of strong income incentives to produce more crude oil in. the U.S. was clearly insufficient to overcome negative factors having a bearing on production of crude. 
8. Because of the enormous strategic importance of oil in the economic life of the United States, its notable size in the total activity of the economy and the far-reaching impact of oil imports on the balance of payments, a comprehensive program of price data gathering embracing all major aspects of the petroleum industries' activities, in addition to other information, is needed. Central to this program should be the monitoring of price developments on the three stages of operations of the industry, with particular attention given to the marketers' Iunction because of its large costs and the existence of various levels of distribution through which petroleum products travel from refiners to ultimate consumers. These price data could be of great value locating in time any upsurges in prices, should they occur, and help in the development of a suitable anti-inflationary policy. 